\title{
Records of Bison priscus Bojanus (Artiodactyla, Bovidae) skeletons in Western Siberia
}

\author{
Andrey V. Shpansky*, Svetlana V. Svyatko, Paula J. Reimer \& Sergei V. Titov \\ ABSTRACT. Two skeletons of Bison priscus Bojanus skeletons are described from Pleistocene localities \\ of Grigorievka (Irtysh River, Pavlodar Region) and Krasniy Yar (Ob River, Tomsk Region), south-east of \\ West Siberian Plain. The skulls and postcranial skeletons of these individuals are compared with skulls and \\ large sample of limb bones from the same localities, and with archival data from other sites in Western \\ Siberia. The study showed that the skeletons belonged to individuals of different sex and geological age. \\ The individual from Krasniy Yar has been determined as an old female with a geological age of $45 \mathrm{ka}$. The \\ skeleton from Grigorievka apparently belongs to a male and it originates from the beginning of Middle \\ Neopleistocene deposits. Long bone dimensions have a large overlap in males and females. Most suitable \\ for sex determination are measurements of the relative diaphyseal width of radius, tibia, and metacarpals.
}

KEY WORDS: Bison, skeletons, Pleistocene, Western Siberia.

AndreyV. Shpansky [shpansky@ggf.tsu.ru], Department of Paleontology and Historical Geology, Tomsk State University, Lenin Ave., 36, Tomsk 634050,Russia; SvetlanaV. Svyatko [s.svyatko@qub.ac.uk] \& Paula J. Reimer [p.j.reimer@qub.ac.uk], ${ }^{14}$ CHRONO Centre for Climate, the Environment, and Chronology, School of Geography, Archaeology and Palaeoecology, Queen's University Belfast, Belfast, Northern Ireland, UK; Sergei V. Titov [titovs80@mail.ru], Environmental Research Centre "Monitoring”; Toraigyrov Pavlodar State University, Pavlodar, Kazakhstan.

\section{Находки скелетов бизонов Bison priscus Bojanus (Artiodactyla, Bovidae) в Западной Сибири}

\author{
А.В. Шпанский, С.В.Святко, П.Реймер, С.В. Титов
}

РЕЗЮМЕ. Описаны два скелета Bison priscus Bojanus из местонахождений Григорьевка на р. Иртыш (Павлодарская область) и Красный Яр на р. Обь (Томская область) юго-востоке Западно-Сибирской равнины. Проведено сравнение черепов и посткраниальных остатков этих скелетов с другими черепами и большими выборками по костям конечностей из этих же местонахождений и литературными данными по другим местонахождениям Западной Сибири. Установлено, что скелеты имеют разную половую принадлежность и геологический возраст. Скелет из Красного Яра принадлежит старой самке и имеет геологический возраст 45 тыс. лет, а скелет из Григорьевки принадлежит самцу и происходит из отложений начала среднего неоплейстоцена. Размеры трубчатых костей имеют большое перекрытие значений для самцов и самок. Наиболее диагностичными для определения пола являются значения относительной ширины диафиза у лучевых, метакарпальных и больших берцовых костей.

КЛЮЧЕВЫЕ СЛОВА: Bison, скелеты, плейстоцен, Западная Сибирь.

\section{Introduction}

Bison remains are relatively common in sediments of the Middle and Late Neopleistocene of Western Siberia. As an example, in multi-species localities of Krasniy Yar and Taradanovo (Novosibirsk Region), Grigorievka (Pavlodar Region), and Krasniy Yar (Tomsk Region $)^{1}$, the proportion of bison remains amounts up to $48 \%$ of the total number of bones recovered (Tables 1 and 2, Vasiliev, 2008). But finds of complete

\footnotetext{
* Corresponding author

${ }^{1}$ Note that two different sites with the name "Krasniy Yar" are mentioned in this paper. To avoid confusion, here and further in the text, the exact location of the site is specified in brackets.
}

skeletons or even their articulated fragments are rare. Occasionally, the remains represent postcranial skeletons (Shpansky, unpublished data). In the West Siberian Plain, only three relatively complete articulated bison skeletons have been discovered to date. These include records in the sites of Vladimirskaya mine (Tom River, Kemerovo Region), Grigorievka Village (Irtysh River, Pavlodar Region), and Krasniy Yar Village (Ob River, Tomsk Region; Fig. 1). The burial in the Vladimirskaya mine was described by P.M. Ryzhkov (1927). The skeleton was located in diagonally layered alluvial sands at a depth about $6 \mathrm{~m}$ and comprised 34 bones, including a skull fragment and both mandibular rami. The two other finds have not been published yet (apart from morphological analysis of 
Table 1. The species composition of mammals in the Grigorievka site (Pavlodar Region).

\begin{tabular}{|l|c|c|c|}
\hline \multicolumn{1}{|c|}{ Species } & NR & NR, $\%$ & MNI \\
\hline \multicolumn{4}{|c|}{ Mammoth faunal complex } \\
\hline Mammuthus primigenius (Blumenbach) & 7 & 2.5 & $3 ?$ \\
\hline Coelodonta antiquitatis (Blumenbach) & 8 & 2.9 & 2 \\
\hline Equus sp. & 7 & 2.5 & 1 \\
\hline \multicolumn{4}{|c|}{ Irtysh faunal complex } \\
\hline Canis lupus L. & 1 & 0.4 & 1 \\
\hline Mammuthus ex gr. trogontherii (Pohlig) & 24 & 8.7 & $2 ?$ \\
\hline Elasmotherium sibiricum Fischer & 8 & 2.9 & 2 \\
\hline Equus ex gr. mosbachensis-germanicus & 3 & 1.1 & 2 \\
\hline Bison priscus Bojanus & $130+42 *$ & 46.9 & 9 \\
\hline Bos primigenius Bojanus & 1 & 0.4 & 1 \\
\hline Saiga tatarica L. & 3 & 1.1 & 2 \\
\hline Megaloceros giganteus ruffi Nehr. & 16 & 5.8 & 4 \\
\hline Cervus elaphus L. & $26+18$ & 15.9 & 4 \\
\hline Camelus knoblochi Nehr. & 2 & 0.7 & 1 \\
\hline Unidentified & 23 & 8.3 & \\
\hline Total & $277+42 *$ & & $34 ?$ \\
\hline
\end{tabular}

* the number of bison bones found in 2008 .

Table 2. The species composition of the mammoth fauna in the Krasniy Yar site (Tomsk Region) by 2015.

\begin{tabular}{|l|c|c|c|c|}
\hline \multicolumn{1}{|c|}{ Species } & NR & NR, $\%$ & MNI & MNI, $\%$ \\
\hline Castor fiber L. & 11 & 0.2 & 4 & 0.9 \\
\hline Lepus timidus L. & 6 & 0.1 & 3 & 0.7 \\
\hline Bison priscus Boj. & 2253 & 42.2 & $157+3$ & 35.1 \\
\hline Ovibos pallantis H. Smith & 7 & 0.13 & 1 & 0.22 \\
\hline Saiga tatarica L. & 22 & 0.4 & 3 & 0.7 \\
\hline Alces alces L. & 398 & 7.5 & 27 & 5.9 \\
\hline Megaloceros giganteus Blum. & 242 & 4.5 & 21 & 4.6 \\
\hline Cervus elaphus L. & 102 & 1.9 & 6 & 1.3 \\
\hline Rangifer tarandus L. & 29 & 0.5 & 3 & 0.7 \\
\hline Coelodonta antiquitatis Blum. & 416 & 7.8 & 44 & 9.6 \\
\hline Equus ex gr. gallicus Prat & 1079 & 20.2 & 125 & 27.4 \\
\hline Mammuthus primigenius Blum. & 534 & 10.0 & 33 & 7.2 \\
\hline Panthera spelaea Goldf. & 49 & 0.9 & 5 & 1.1 \\
\hline Ursus savini rossicus Vereshchagin & 21 & 0.4 & 3 & 0.7 \\
\hline Ursus arctos L. & 8 & 0.15 & 3 & 0.7 \\
\hline Crocuta spelaea Goldf. & 2 & 0.04 & 1 & 0.22 \\
\hline Canis lupus L. & 25 & 0.5 & $10+1 ?$ & 2.4 \\
\hline Gulo gulo L. & 3 & 0.06 & 2 & 0.44 \\
\hline Meles leucurus Hodgson & 2 & 0.04 & 1 & 0.22 \\
\hline Unidentified & 128 & 2.4 & - & - \\
\hline Total (n=19) & 5337 & 100 & 456 & 100 \\
\hline
\end{tabular}

skull of the Krasniy Yar individual; Shpansky, 2006), and therefore are presented in this paper. In all cases, crania have been preserved, which allows the comparison of their morphology with that of postcranial skeletons, as well as evaluation of sex characteristics and intraspecific variability of Bison priscus Bojanus, 1827.

Being a dominant species amongst fossil fauna, bisons are well known to palaeontologists, however, generally the skulls show a very high variability in their morphology, particularly of the frontal part and horncore. Based on length and curvature of the horn-cores, as well as their position relatively to frontal and occipital bones, a number of $B$. priscus subspecies have been defined (Gromova, 1935; Rusanov, 1975; Flerov, 1979). Following these characteristics and in the absence of direct radiocarbon $\left({ }^{14} \mathrm{C}\right)$ dates of the remains, further systematic and biostratigraphycal reconstructions have been made. A similar analysis of the bison skulls with different morphology has been carried out earlier for the Krasniy Yar site in the Tomsk Region (Shpansky, 2006); this also did not include ${ }^{14} \mathrm{C}$ dating of the remains. Further investigation of the mass bison burials 


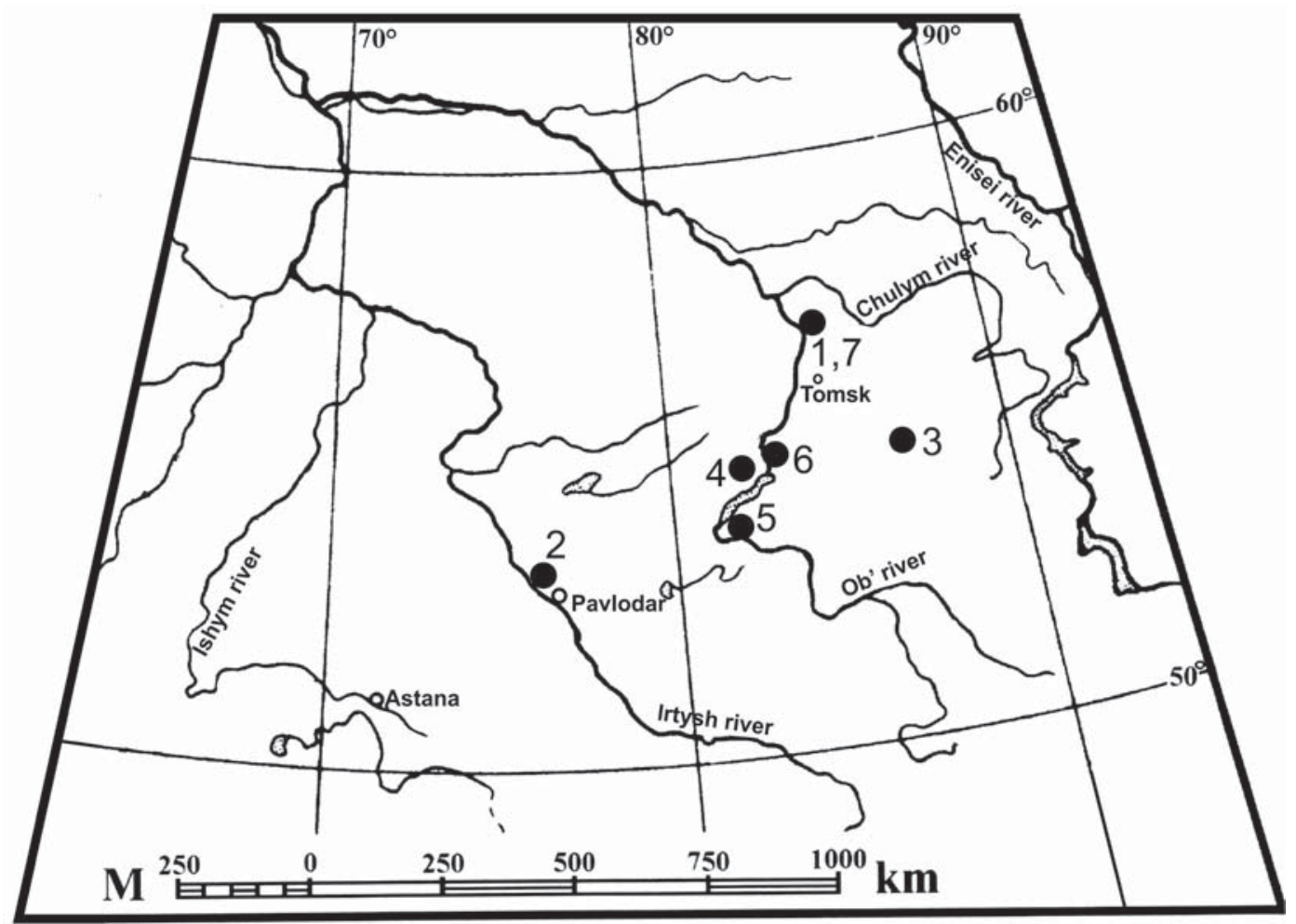

Fig. 1. Location map of the Bison priscus sites in Western Siberia. Skeletons: 1 - Krasniy Yar (Tomsk Region), 2 Grigorievka (Pavlodar Region), 3 - Vladimirskaya mine (Kemerovo Region). Main localities with prevailing remains of bisons: 4 - Chik, 5 - Taradanovo, 6 - Krasniy Yar (Novosibirsk Region), 7 - Krasniy Yar (Tomsk Region).

(Vasiliev, 2008 and current study), supplemented with the results of ${ }^{14} \mathrm{C}$ dating (see below), demonstrated that the frontal part and horn-core morphology is highly variable inside species for the individuals from various localities. The interpretation is further complicated by age-related differences in individual development and sexual dimorphism.

Here, we present a descriptive analysis of two $B$. priscus fragmented adult skeletons of different sexes from the Grigorievka Village (Irtysh River, Pavlodar Region) and Krasniy Yar village (Ob River, Tomsk Region) and compare them with a number of isolated bison remains from different localities of the West Siberian Plain. The analysis allowed us to define a stable complex of sex-determining cranial morphological features, which could be correlated with postcranial remains. Significant dimensional overlap between large females and small males, on the opposite, makes it difficult to estimate sex of an animal from the individual bones.

\section{Materials and methods}

The paper presents the results of the study of two skeleton fragments of bisons. The fragment from the Grigorievka site (Pavlodar Region; MP PGPI 1222) comprises of 42 bones, including cranial bones (right maxillare and premaxillare, horn and frontale, and a fragment of left horn), both branches of mandible, 18 vertebrae, right scapula, left and right humeri, left and right radii and ulnae, left and right metacarpals $3+4$, pelvis (right ilium), left and a fragment of right femurs, patella, left and right tibiae and several fragments of ribs and vertebrae spinous processes). Currently, the assembled skeleton (Fig. 6) is exhibited in the Museum of Nature of the Arkalyk Pedagogical Institute (Kostanay Region, Kazakhstan).

The skeleton from Krasniy Yar (Tomsk Region; PM TSU, 8/1-53) comprises of 53 bones, including cranium, both branches of mandible, seven cervical vertebrae, left forelimb without scapula and with a damaged proximal humerus, distal part of the right forelimb and right tibia (tibia PM TSU 5/1443).

The following skeletal materials have been used for comparison:

a) four bison skulls from the Grigorievka Village (MP PGPI 584, MP PGPI 1176, MP PGPI 1179, and one individual without ID), bison skulls from Krasniy Yar (Tomsk Region; PM TSU 5/1511 and PM TSU 5/ 1744), serial material of bison postcranial bones from Krasniy Yar (Tomsk Region; more than 1500 bones in total);

b) published data on finds of bisons in Western Siberia, including the skeleton fragment of a male from 
Table $3 .{ }^{14} \mathrm{C}$ dates from the bones of various megafaunal species from the sites of Grigorievka and Krasniy Yar (Tomsk Region). ${ }^{14} \mathrm{C}$ ages were calibrated with IntCal13 (Reimer et al., 2013).

\begin{tabular}{|c|c|c|c|c|c|c|c|c|}
\hline Provenance & Species & Museum ID & Bone & Lab ID & $\begin{array}{c}\% \\
\text { collagen } \\
\end{array}$ & $\mathrm{C}: \mathrm{N}_{\mathrm{at}}$ & ${ }^{14} \mathrm{C}$ age $\mathrm{BP}$ & $\begin{array}{l}\text { Calibrated } \\
\text { ages }(2 \mathrm{sd})\end{array}$ \\
\hline \multirow{3}{*}{ Grigorievka } & \multirow{2}{*}{ Bison priscus } & \multirow{2}{*}{$\begin{array}{l}\text { MP PGPI } \\
1222-38\end{array}$} & \multirow{2}{*}{ femur } & $\begin{array}{l}\text { UBA- } \\
21203\end{array}$ & $\mathrm{n} / \mathrm{a}$ & $\mathrm{n} / \mathrm{a}$ & (no collagen) & $\mathrm{n} / \mathrm{a}$ \\
\hline & & & & $\begin{array}{l}\text { UBA- } \\
21204\end{array}$ & $\mathrm{n} / \mathrm{a}$ & $\mathrm{n} / \mathrm{a}$ & (no collagen) & $\mathrm{n} / \mathrm{a}$ \\
\hline & $\begin{array}{l}\text { Megaloceros } \\
\text { giganteus }\end{array}$ & $\begin{array}{l}\text { PM TSU } \\
55 / 1\end{array}$ & skull & $\begin{array}{l}\text { UBA- } \\
25871 \\
\end{array}$ & $\mathrm{n} / \mathrm{a}$ & $\mathrm{n} / \mathrm{a}$ & (no collagen) & $\mathrm{n} / \mathrm{a}$ \\
\hline \multirow{8}{*}{ Krasniy Yar } & Bison priscus & $\begin{array}{l}\text { PM TSU } \\
5 / 1764\end{array}$ & tibia & $\begin{array}{l}\text { SB RAS- } \\
5555\end{array}$ & $\mathrm{n} / \mathrm{a}$ & $\mathrm{n} / \mathrm{a}$ & $18505 \pm 215$ & $\begin{array}{l}21859- \\
22856 \mathrm{BP}\end{array}$ \\
\hline & $\begin{array}{l}\text { Mammuthus } \\
\text { primigenius }\end{array}$ & $\begin{array}{l}\text { PM TSU } \\
5 / 1741 \\
\end{array}$ & tusk & $\begin{array}{c}\text { SB RAS- } \\
5201\end{array}$ & $\mathrm{n} / \mathrm{a}$ & $\mathrm{n} / \mathrm{a}$ & $25650 \pm 420$ & $\begin{array}{l}28888- \\
30756 \text { BP }\end{array}$ \\
\hline & \multirow{2}{*}{$\begin{array}{l}\text { Stephano- } \\
\text { rhinus } \\
\text { kirchber- } \\
\text { gensis }\end{array}$} & \multirow{2}{*}{$\begin{array}{l}\text { PM TSU } \\
5 / 740\end{array}$} & \multirow{2}{*}{ astragal } & $\begin{array}{l}\text { UBA- } \\
21200 \\
\end{array}$ & $\mathrm{n} / \mathrm{a}$ & $\mathrm{n} / \mathrm{a}$ & (no collagen) & $\mathrm{n} / \mathrm{a}$ \\
\hline & & & & $\begin{array}{l}\text { UBA- } \\
21201 \\
\end{array}$ & $\mathrm{n} / \mathrm{a}$ & $\mathrm{n} / \mathrm{a}$ & (no collagen) & $\mathrm{n} / \mathrm{a}$ \\
\hline & Bison priscus & $\begin{array}{l}\text { PM TSU } \\
5 / 1744 \\
\end{array}$ & skull & $\begin{array}{c}\text { UBA } \\
25872 \\
\end{array}$ & 4.0 & 3.3 & $>44926$ & $\mathrm{n} / \mathrm{a}$ \\
\hline & \multirow{2}{*}{ Bison priscus } & \multirow{2}{*}{$\begin{array}{l}\text { PM TSU } \\
8 / 10\end{array}$} & \multirow{2}{*}{$\begin{array}{l}\text { hume- } \\
\text { rus }\end{array}$} & $\begin{array}{l}\text { UBA- } \\
21202\end{array}$ & $6.7^{*}$ & $3.3^{*}$ & $43665 \pm 1456^{* *}$ & $\begin{array}{l}44618- \\
49824 \text { BP }\end{array}$ \\
\hline & & & & $\begin{array}{l}\text { UBA- } \\
21643 \\
\end{array}$ & $\mathrm{n} / \mathrm{a}$ & $\mathrm{n} / \mathrm{a}$ & $46116 \pm 2791$ & $\mathrm{n} / \mathrm{a}$ \\
\hline & Bison priscus & $\begin{array}{l}\text { PM TSU } \\
5 / 1511 \\
\end{array}$ & skull & $\begin{array}{l}\text { UBA- } \\
25870 \\
\end{array}$ & 1.6 & 3.4 & $37917 \pm 913$ & $\begin{array}{l}40520- \\
43489 \text { BP } \\
\end{array}$ \\
\hline
\end{tabular}

* Mean values for UBA-21202/6-15 are available and presented.

** The date represents fifteen ${ }^{14} \mathrm{C}$ ages (UBA $21202 / 1-15$ ) combined using uncertainty-weighted means.

the Vladimirskaya mine (Kemerovo Region; 34 bones in total, stored in the Tomsk Polytechnic University; Ryzhkov, 1927).

Bone measurements were carried out following $\mathrm{V}$. Gromova (1935) using a calliper and a measuring tape with an accuracy of $1 \mathrm{~mm}$. Letter " $\mathrm{C}$ " in front of the numerical values of a number of measurements indicates that they are not complete due to damage of bones. For sex determination, the following indexes have been used on skulls:

a) frontal index: ratio of medial frontal length and the minimum frontal width, $\mathrm{cm}^{2}$;

b) horn-core base flatness index: ratio of the dorsoventral breadth of the horn-core base to cranio-caudal breadth of the horn-core base, $\%$;

c) horn-core curvature index: the ratio of the straight distance between the base and the tip of the horn-core to the length of the horn-core along the maximum, $\%$;

d) horn-core massiveness index: the ratio of the horn-core base circumference to the length of horncore along the maximum, $\%$.

For the long bones, the ratio (\%) of the diaphysis middle width to the length of the bone was used for sex determination.

\section{AMS ${ }^{14} \mathrm{C}$ dating}

In total, twenty five radiocarbon dates have been obtained from 8 individuals (Table 3 ). For the consistency, we have provided the results of the radiocarbon dating in the associated sections of the Introduction part.

The majority of the dates (laboratory ID UBA; $n=23)$ were obtained from bone collagen samples prepared and analysed in the ${ }^{14} \mathrm{CHRONO}$ Centre for Climate, the Environment and Chronology (Queen's University Belfast) using NEC compact 0.5 MV AMS.

Sample bone surfaces were cleaned. Preparation of collagen was based on an ultrafiltration method (Brown et al., 1988; Bronk Ramsey et al., 2004) and included bone demineralization $(2 \% \mathrm{HCl})$, gelatinization $\left(\right.$ at $58^{\circ} \mathrm{C}$ for 16 hours), filtration, ultrafiltration (using Vivaspin $15 \mathrm{~S}$ ultrafilters with MWCO $30 \mathrm{kDa}$; 3000-3500 rev/ min for 30 minutes), and freeze-drying. The dried collagen was stored in a desiccator.

Prepared collagen samples were sealed under vacuum in quartz tubes with an excess of $\mathrm{CuO}$ and combusted at $850^{\circ} \mathrm{C}$. The $\mathrm{CO}_{2}$ was converted to graphite on an iron catalyst using a zinc reduction method (Slota et al., 1987). The graphite was then pressed to produce a "target" and this was measured by AMS. The ${ }^{14} \mathrm{C}$ age and one standard deviation were calculated using the Libby half-life (5568 years) following the conventions of Stuiver \& Polach (1977). The age uncertainty included the measurement error and the long term variability in the background. A laboratory error multiplier of 1.3 for bones was applied to the sample uncertainty. The radiocarbon ages were corrected for isotopic fractionation using the AMS-measured $\delta^{13} \mathrm{C}$ and calibrated 

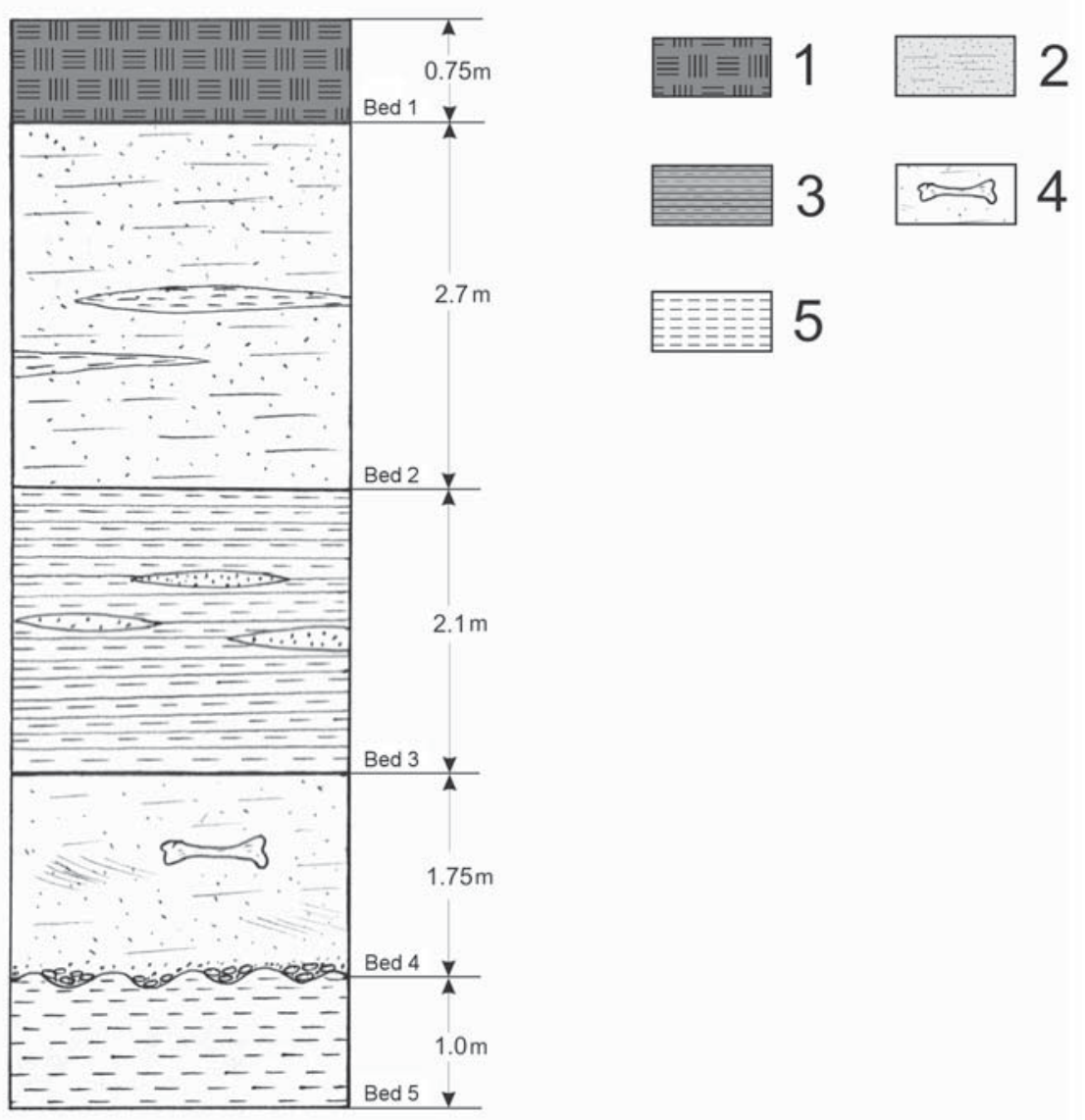

Fig. 2. Schematic cross-section of the Quaternary deposits near the Grigorievka Village (Pavlodar Region): 1 - soil; 2 fine- and medium grained sands; 3 - horizontally-bedded clays with sand lenses; 4 - horizontally and diagonally-bedded sands with mammal remains; 5 - grey-blue sticky clays.

using Calib 7.0 programme (Stuiver et al., 2013) and IntCal13 calibration curve (Reimer et al., 2013).

For samples analyzed in the ${ }^{14} \mathrm{CHRONO}$ Centre, the bone collagen content varied between 1.6 and $7.0 \%$, which indicates very good collagen preservation (van Klinken, 1999; Table 3). The C: $\mathrm{N}_{\text {atomic }}$ ratio was within the accepted range 2.9-3.6, also characteristic of wellpreserved collagen (DeNiro, 1985).

Two dates (laboratory code SB RAS) were obtained from the Laboratory of Geology and Palaeoclimatology of Cenozoic using liquid scintillation method and ${ }^{14} \mathrm{C}$ half-life of 5570 years (see also Shpansky, 2006). The details of pretreatment protocols for these laboratories are not available.

The following abbreviations have been used: MP PGPI (Museum of Nature, Pavlodar State Pedagogical Institute, Kazakhstan); PM TSU (Paleontological Museum of Tomsk State University, Russia); uppercase P and $\mathrm{M}$ (upper permanent premolars and molars); lowercase $\mathrm{p}$ and $\mathrm{m}$ (lower permanent premolars and molars); $\mathrm{NR}$ - number of remains; MNI - minimum number of individuals; ID - identifier, MIS (Marine Isotope Stage).
The study uses the General Stratigraphic Scale of Russia, with Neopleistocene correlating to Middle + Late Pleistocene of ISC, with early Neopleistocene corresponding to early Middle Pleistocene, middle Neopleistocene, to MIS11-6, late Neopleistocene, to MIS51 of International usage.

\section{Geographical and geological character- istics of the sites}

Grigorievka (52³6'38.1"N, 764 44'47.4"E)

The site is located on the right bank of the Irtysh River, near the village of Grigorievka, $40 \mathrm{~km}$ north from Pavlodar city (Kazakhstan, Fig. 1). Above the flood-plain, a river terrace is exposed over a length of 2 $\mathrm{km}$, the bank experiences constant erosion. Terrace deposits represent alluvial sediments of Middle to Late Neopleistocene (The unified..., 2000). The following beds are exposed downsection from the terrace top (Fig. 2):

1. Modern soil, getting lighter and more brownish towards the base, with a significant amount of medium- 
grained dispersed sand. Thickness - $0.75 \mathrm{~m}$, depth $0.75 \mathrm{~m}$.

2. Light brown fine- to medium-grained sand, horizontally layered, highly compact, with small thin layers of carbonized loams in the upper part. Thickness - 2.7 $\mathrm{m}$, depth $-3.45 \mathrm{~m}$.

3. Brown dense thin horizontally- or wavy-layered loams. The exposed surface shows well visible white crusts, possibly indicating salination processes. In the middle part, there are long, up to $15 \mathrm{~cm}$ thick, lenses of coarse-grained sand. Thickness $-2.1 \mathrm{~m}$, depth $5.55 \mathrm{~m}$.

4. Alternating sands, horizontally- or diagonallybedded, yellow-ginger, sometimes brown of iron oxides, sometimes well washed and well-layered, bluish. The bed unconformably overlays the clays of bed 5 . Thickness $-1.75 \mathrm{~m}$, depth $-7.3 \mathrm{~m}$.

5 . Thick, grey, sometimes very dense clay. In outcrops downstream, the top of the bed shows erosional pockets filled with fine gravel and coarse-grained sand. The surface of pockets and gravel infillings are compact and ferruginate, brown coloured, locally with darker colour of the gravel cement. Observed thickness - 1.0 $\mathrm{m}$, depth $-8.3 \mathrm{~m}$.

The boundary between beds 5 and 4 is very vague and rough; in some parts sands laterally sink below the water line. The species composition of the site and the preservation of the bones suggest the presence of two depositions of various periods (Table 1). The majority of the bones were unambiguously older and taxonomically represented the "Irtysh faunal complex" species (start of Middle Neopleistocene, Tobolsk Horizon; Stratigraphical scheme of West Siberian Plain; MIS 911; Shpansky, 2009). At the time of the lowest water level (in July and August), the bones were located in the bottom of the washed sands of bed 4 or below the water line (up to $1 \mathrm{~m}$ ) on the washed clay surface of the layer 5. Bones were of average to good preservation, without traces of polishing, ash-grey in colour, with multiple speckles of manganese oxides. Some bones were rustyred, sometimes with periosteum peeled off the outer layer of compact bone, and often brittle. The sharp ends of the bones suggest that they were fractured after their deposition, perhaps as a result of the modern erosion of the bearing sediments. Among the remains, there was a high percentage of crania and mandibles of Bison priscus, red deer (Cervus elaphus) and giant deer (Megaloceros giganteus) (Shpansky et al., 2007; Shpansky, 2011). This may suggest that the original burial deposit located on the border of layers 4 and 5 was exposed during the low water level in the Irtysh River. The problems with excavation of extraction of bone remains from under water resulted in lower number of specimens available for sampling, distortion of proportions of remains from various species and incompleteness of the site species composition, as well as in a lower number of smaller bones, individual teeth and remains of small animals. But in general, the sample is large and diverse, with a significant number of crania and mandi- bles, and includes the bison skeleton described below. The palynological spectrum from the base of the layer 4 is dominated by herbaceous pollen (52\%), particularly sagebrush (Artemisia sp.) and Chenopodiaceae (analysed by S.N. Babenko, unpublished data). Arboreal pollen composes ca. $40 \%$ of the assemblage, and is dominated by pine (Pinus sp.) and birch (Betula sp.). The available palynological data indicate a relatively warm environment and the riverine landscape dominated by open biotopes and small-leaved and coniferous forests.

Another, minor group of bones were represented by isolated remains of typical megafaunal species, including Mammuthus primigenius (Blumenbach), Coelodonta antiquitatis (Blumenbach), and Equus sp. These bones were brown, fragmentary (including woolly rhino mandibles and mammoth teeth), and suggested a possible event of redeposition. They rested on the washed sand surface (layer 4) and probably had either been washed out from earlier sediments (layer 3 ) or carried to the site by the Irtysh River.

In 2012, an attempt was made to determine the age of the Grigorievka Bison priscus skeleton (MP PGPI 1222) using AMS radiocarbon dating of bone collagen in the ${ }^{14} \mathrm{CHRONO}$ Centre for Climate, the Environment, and Chronology, Queen's University Belfast, UK (sample IDs UBA-21203 and UBA-21204). However, in that case the bone collagen had been degraded and yielded no collagen. This was also the case for the sample of giant deer (Megaloceros giganteus; PM TSU $55 / 1$ ) skull from the same context (UBA-25871).

Krasniy Yar $\left(57^{\circ} 07^{\prime} 41.5^{\prime \prime} \mathrm{N}, 84^{\circ} 31^{\prime} 32.1^{\prime \prime} \mathrm{E}\right)$

The site is located near the settlement of Krasniy Yar (Krivosheinskiy District, Tomsk Region), 105 km north from the Tomsk city, on the left bank of the $\mathrm{Ob}$ River channel to the east of the Sargulinskiy Island (Fig. 1 and 3). Recently refined geological settings of the outcrops demonstrate that the Ob River erodes here Upper Neopleistocene deposits (Shpansky, 2006, 2014). The following beds are exposed downsection from the terrace top:

1. The cultural bed represents an ash grey soil interrupted with cauldrons, traces of fire-pits, remains of wood, charcoal, decomposed plants and rare bones of modern animals. Thickness $-0.2-0.5 \mathrm{~m}$, depth $-0.2 \mathrm{~m}$.

2. Pale-grey sandy loams, macroporous, structureless silt, with re-deposited humus spots at its top part. Thickness - $0.6 \mathrm{~m}$, depth $-0.8 \mathrm{~m}$.

3. Quartz consertal sands, horizontally thin-layered, bluish-grey, micaceous, sometimes yellow-grey with iron ortsand-type concretions and streaks. At the bottom part, the sands are lens-crossbedded, contain clay inclusions, from grey and greenish grey to brown or red-brown. At the top part, isolated Alces alces, Bison priscus, and Mammuthus primigenius bones have been found. Thickness $-2.2 \mathrm{~m}$, depth $-3.0 \mathrm{~m}$.

4. Sticky clays, grey or blue-grey, bedded with thin layers of compact iron brown and red-brown clays. Thickness - 1.5-2.5 m, depth $-5.5 \mathrm{~m}$. 


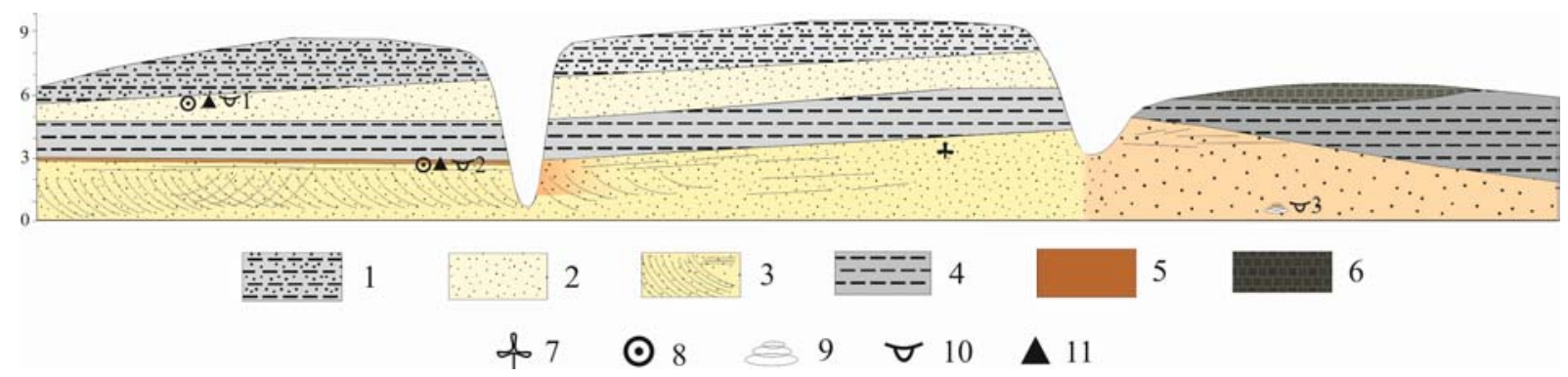

Fig. 3. Schematic cross-section of the Quaternary deposits near the Krasniy Yar Village (Tomsk Region): 1 - modern soil bed; 2 - inequigranular sand; 3 - sandy loams; 4 - horizontally-bedded sands; 5 - cross-bedded sands; 6 - horizontallylayered clays; 7 - peat; 8 - remains of molluscs; 9 - mammalian remains; 10 - macro-plant remains; 11 - palynological samples.

5. Clay loams, brown with red-brown (of about 1.5$2 \mathrm{~cm}$ thick) streaks at the top and base of the bed. The skeletal fragment of Bison priscus (PM TSU 8/1-53) was found in this bed. Thickness $-0.2 \mathrm{~m}$, depth $5.7 \mathrm{~m}$.

6. Horizontally- to cross-bedded sand (with varying direction of interbeds), fine- to medium-grained, with gravel lenses, red to dark rusty. The bed contains large amount of plant detritus and separate upright stumps. The base of the bed yielded numerous remains of large mammals of the Mammoth fauna and redeposited remains of Mammuthus trogontherii chosaricus, Stephanorhinus kirchbergensis, Equus ex gr. mosbachensisgermanicus. Thickness - 2.5-3.5 m, depth - $9.2 \mathrm{~m}$.

The structure of the main part of the outcrop represents a typical second alluvial terrace above the floodplain of the Ob River, which consists of a sequence of channel and flood-plain sediments. In the right eroded part of the section (Fig. 3) the thickness of clays (bed 4) reaches $5 \mathrm{~m}$, and at the top it is covered discordantly by the large peat lens $450 \mathrm{~m}$ long and $1.5 \mathrm{~m}$ thick maximum. The peat deposit is relatively young (not older than 300 years), as at the top part it contains multiple tree trunks with signs of agricultural utilisation.

The site has been being investigated for more than 20 years. Within the outcrop, three clusters of bones have been identified in alluvial deposits. From sands of bed 3, several bones of mammoth fauna mammals have been extracted. The Bison priscus tibia (PM TSU 5/ 1764) and Mammuthus primigenius tusk (PM TSU 5/ 1741) have been dated (Table 3) to 21860-22860 cal BP (SB RAS-5555) and 28890-30760 cal BP (SB RAS-5201) respectively. The main bone deposits, including skull fragments, were located in sands of layer 6 . One of the bone deposits (which contained the Bison priscus skeleton, PM TSU 8/1-53, described below) was located in the sand roof and a thin layer of loam (layers 5 and 6) $50 \mathrm{~m}$ downstream from the mouth of Chernaya Rechka River.

The main part of pollen spectrum (identification by I.A. Sevastianova and S.N. Babenko, unpublished data) from layer 5 is represented by arboreal pollen (42.1\%), mainly pine (Pinus sylvestris, P. sibirica); birch (Betula pendula) and willow (Salix sp.) pollen constitute a minor part. The herbaceous group ( $7.1 \%$ in total) is represented by single grains of Asteraceae, Chenopodiaceae, Cichorieae, as well as abundant pollen of wormwood (Artemisia sp.). Spores of green moss (Bryales sp.) and lycopod (Lycopodium sp.) are less abundant $(1.6 \%)$. The palynological spectrum points to warm and humid conditions during the time of formation of deposits. The majority of bones (including skulls of bisons, horses, and mammoths) originate from the base of bed 6 and from coastal shallow down the stream, where the bones are being washed out. In total, more than 5500 individual bones / bone fragments from 19 large mammal mammoth faunal species have been unearthed (Table 2). Isolated remains of birds and fish have also been recovered, including ca. twenty teeth and bones of Stephanorhinus kirchbergensis Jager, which possibly have been re-deposited from younger layers (Shpansky \& Billia, 2012). The preservation of the bones (in particular their color and weight) is similar to that of mammoth fauna. Therefore, an attempt has been made to obtain the AMS ${ }^{14} \mathrm{C}$ dates of $S$. kirchbergensis astragalus (PM TSU 5/740), which also yielded no collagen (UBA-21200 and UBA-21201; Table 3). We can also suggest that $B$. priscus skull (PM TSU 5/ 1744) has been re-positioned, as its large dimension and morphological features are similar to those of B. $p$. priscus $(=B$. p. longicornis) which lived in Middle Neopleistocene. Radiocarbon dating of the skull PM TSU 5/1744 demonstrated a "greater than" age $(>44930$ BP; UBA-25872).

Radiocarbon measurements have also been performed on B. priscus humerus (PM TSU 8/10). In total, fifteen dates have been obtained (ten of them from the homogenised bone collagen sample) from this individual, averaging 43665 \pm 1456 BP (UBA 21202/1-15; 44620-49820 cal BP) (Table 3). The dates were statistically the same at $95 \%$ level using the Ward and Wilson (1978) Chi-squared test in Calib 7.0.4 ( $\mathrm{T}^{\prime}=6.998$; $\left.\chi^{2}(.05)=23.7\right)$. A slightly younger result, 40520-43490 cal BP (UBA-25870), has been obtained for another male $B$. priscus skull (PM TSU 5/1511) from the same deposit. In total, 6 bones have been ${ }^{14} \mathrm{C}$ dated from this site, including two bones from layer 3 and four bones from layers 5 and 6 (the latter included the bone from 


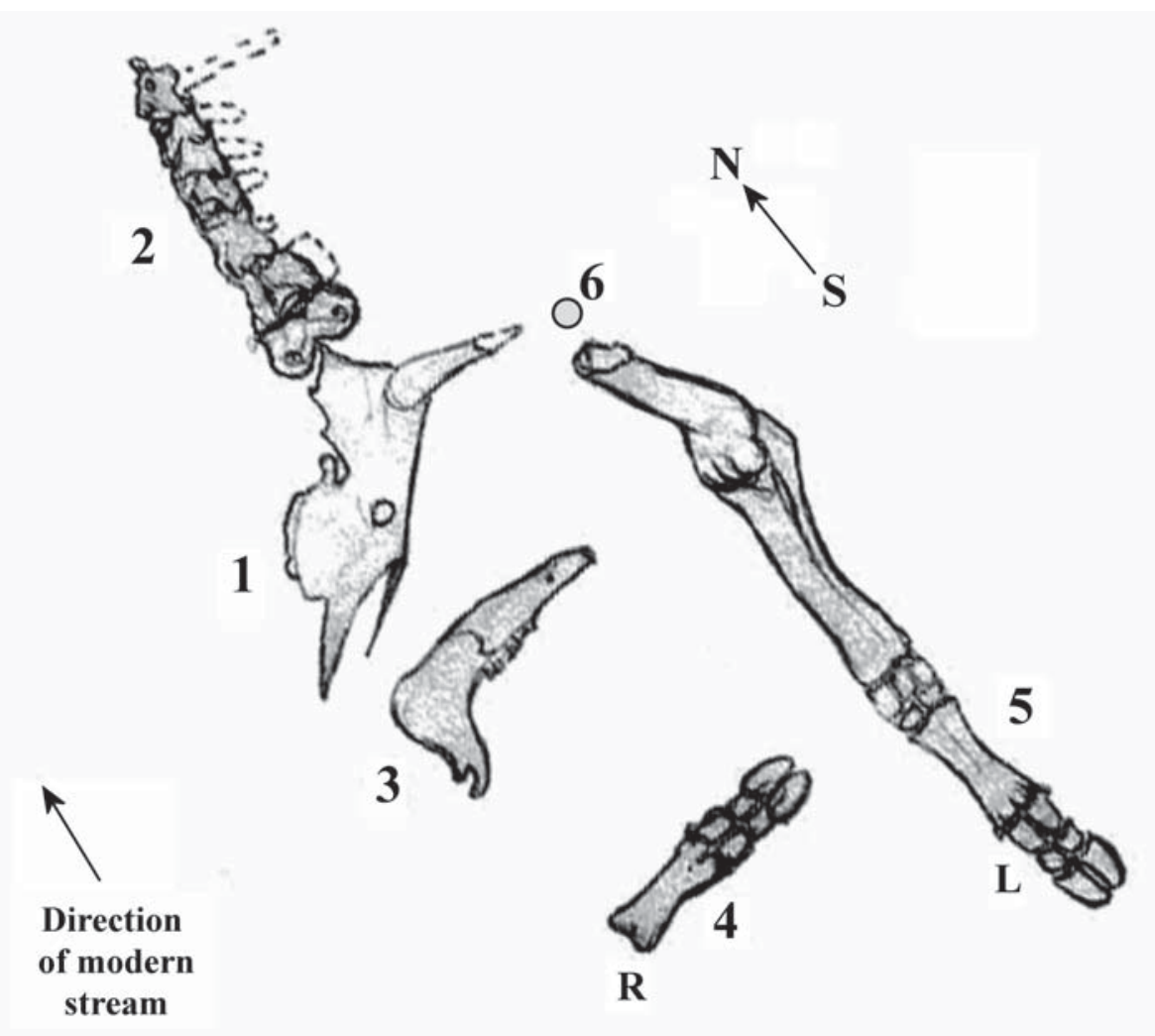

Fig. 4. Location scheme of the Bison priscus bones in the Krasniy Yar site (Tomsk Region): 1 - skull; 2 - neck; 3 - mandible; 4 - distal section of the right forelimb; 5 - left forelimb; 6 - location of vertical rodent burrowing.

the skeleton and also two skulls from other individuals (Table 3). The obtained results allowed us to reconsider the geological age of sediments from these outcrops and their comparison with the Karginsky Horizon (Stratigraphical scheme of West Siberian Plain; MIS 3) - it had been assumed before, that bed 5 dated to a younger period, the end of the Late Neopleistocene or Early Holocene (MIS 1-2; Shpansky, 2006).

\section{Taphonomy of the sites}

\section{Grigorievka}

The B. priscus skeleton was found in 2008 in the bottom of the sand layer (layer 4 ) at the depth of 20-50 $\mathrm{cm}$ below the water level. The depth of burial is ca. $7 \mathrm{~m}$ from the top of the terrace. Bones were found in anatomical order, however, they became extremely fragile due to the considerable slaking. Part of the skeleton (skull, pelvis and a number of other bones) has been destroyed during unearthing, and some bones (distal limbs) have been recently washed away by the Irtysh River, as a result of erosion of the bone-bearing bed. Due to the unusual underwater location of the skeleton, it was not photographed. The recovery of the materials was performed by amateur paleontologists; no rigorous taphonomic records have been made. The bones were red-brown in colour, due to a significant amount of iron oxides in the groundwater. The relief sections of bones carry sand crust cemented by iron oxides. The formation of such crust is probably related to the decomposition of soft tissues after burial. The absence of traces of gnawing on the bones suggests that burial was immediate.

\section{Krasniy Yar}

Bison priscus bones were found in 1993 signaled in the field by a partially exposed male skull. The remains were resting in a small layer of brown loamy clay. The excavated area of about $3 \mathrm{~m}^{2}$ contained a well preserved skull lying on the left side (Shpansky, 1997). The nasal bones and the right horn have minor damages caused by the modern washout of bone-bearing sediments during floods and ice exaration. The skull was articulated with seven cervical vertebrae in anatomical order. Noteworthy, being lighter, the vertebra were positioned downstream from the skull. The lower jaw was located $10 \mathrm{~cm}$ above the skull on its right side, the top dorsal side of the left ramus was pressed towards the right ramus, which resulted in the fracture in the middle of the left mandible (along the first side of the $\mathrm{m} 3)$. The distal section of the right forelimb was located further upstream in anatomical order. Further upstream, perpendicular to the latter, the articulated left forelimb was found (Fig. 4). There was a discoloration 


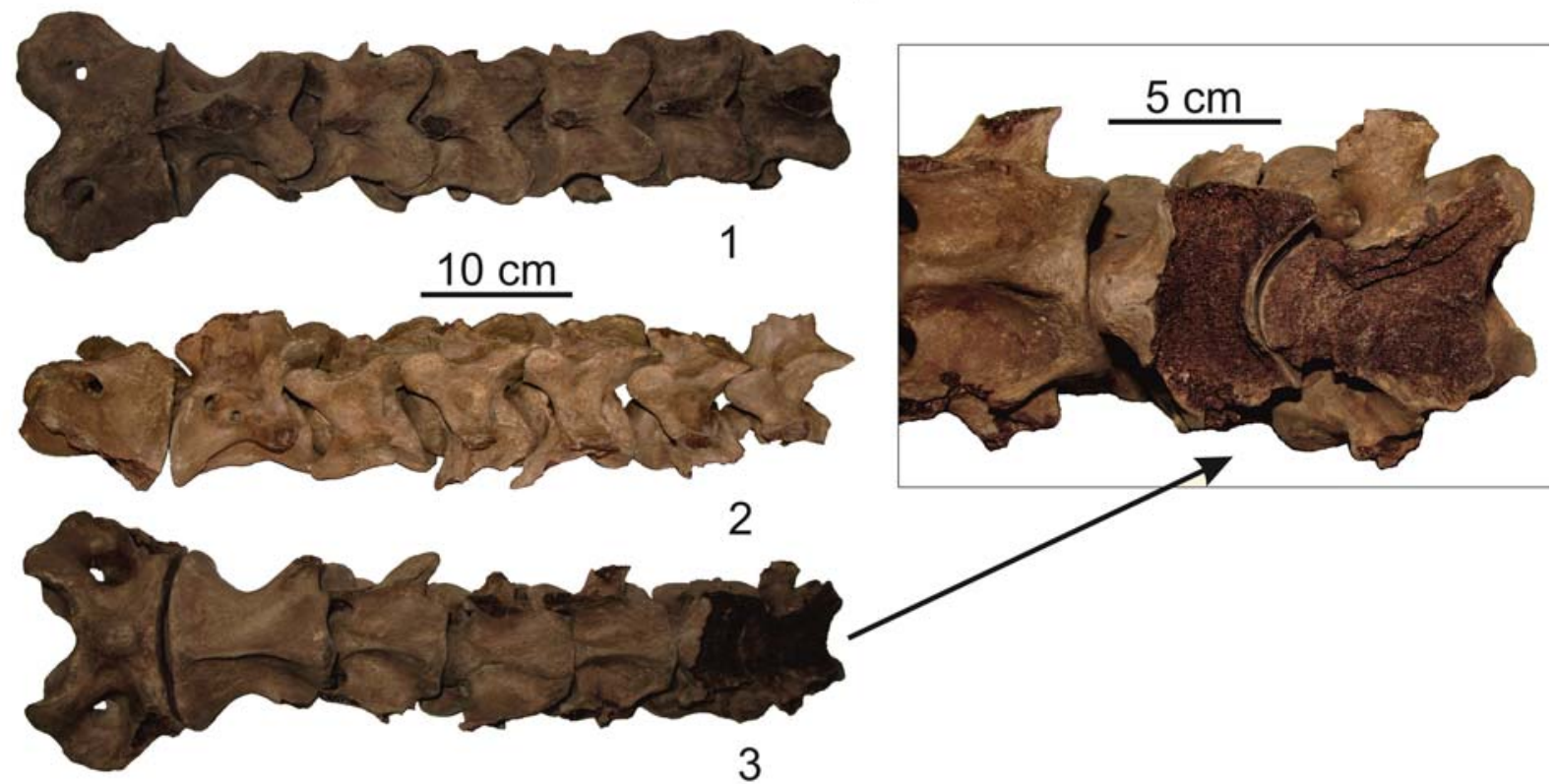

Fig. 5. Strippings on the cervical vertebrae of bison from Krasniy Yar (Tomsk Region): 1 - dorsal view, 2 - lateral view, 3 - ventral view, 4 - the area of the major strippings on the $6^{\text {th }}$ and $7^{\text {th }}$ cervical vertebrae.

of the containing clay towards a brownish-red shade around the bones; the thickness of this margin was $1-$ $1.5 \mathrm{~cm}$. The proximal epiphysis of the left humerus had signs of gnawing, as also did the bodies of $\mathrm{C}_{6}$ and $\mathrm{C}_{7}$ vertebrae, where spinouts processes and large parts of bodies themselves had been completely destroyed. During the excavation of the burial, in overlying "grey" clays, a vertical structure of ca. $5 \mathrm{~cm}$ in internal diameter, with very dense brown-red, ironized walls and light red substance inside was found. The structure is located close to the humerus. It possibly represents an ancient rodent burrowing ("krotovina") produced by a medium-size rodent (presumably ground squirrel), which may have left marks on the bones (Fig. 5). The gnawing marks were made after the deposition of the remains and probably after partial or complete decomposition of the soft tissues (Shpansky \& Pecherskaja, 2006). Tibia (PM TSU 5/1443) of this individual was discovered in 1996, ten metres away from the main burial.

\section{Definition of the location types}

Both studied sites with bison remains are characterised by deposition of the bones in alluvial layers. Similar deposition has also been recorded for the bison skeleton from the "Vladimirskaya" mine (Ryzhkov, 1927). Geologically, the location of the skeletons at the boundary of different layers (siltstone-sand or sandclay) apparently indicates a change of hydrological regime from fast to slow flow or vice versa. Similar abrupt changes are characteristic for meander bars of large rivers. During the flood periods, coarser, sandy deposits accumulate, while during decline of the water level and reduction of the speed and force of the flow thin silt or clay layers are formed. These parts of river valleys are the most favourable for the accumulation of large animal remains, both individual bones and corpse fragments. The above cases apparently represent typical examples of drifted animal corpses. The burials are allochtonous (i.e. the death place of an animal differs from the burial place of its remains). The Grigorievka skeleton is more complete and nearly completely articulated. We can, therefore, suggest that the drift of the corpse was a relatively short, and its deposition occurred rapidly (within one season).

From the Krasniy Yar (Tomsk Region) skeleton, the rear part of the corpse is missing (except for the tibia and apparently pelvis; the latter was found by local residents, however, has not been preserved). Supposedly, the carcass had been drifting for several days. The apparent deposition of the corpse in the water stream is suggested by the fact that long parts of the skeleton (articulated neck and left forelimb) were lying in parallel to each other. Further upstream, the lower jaw and the articulated distal section of the right forelimb were found, perpendicularly to the neck and the other limb. The skull with widely set horns apparently acted as an anchor. The lower jaw and the distal section of the right forelimb were drifted towards the skull (Fig. 4). From the orientation of the bones, the direction of the ancient river current was reconstructed (Shpansky \& Pecherskaja, 2006). The disintegration of the skeleton is accounted for the decomposition process which apparently took place after the body had stayed in water for several days. Gases accumulated in the body during its decomposition led to tearing of the peritoneum skin ("explosion") and a fracture of spine, which contributed to the separation of the body in several parts. Skin 


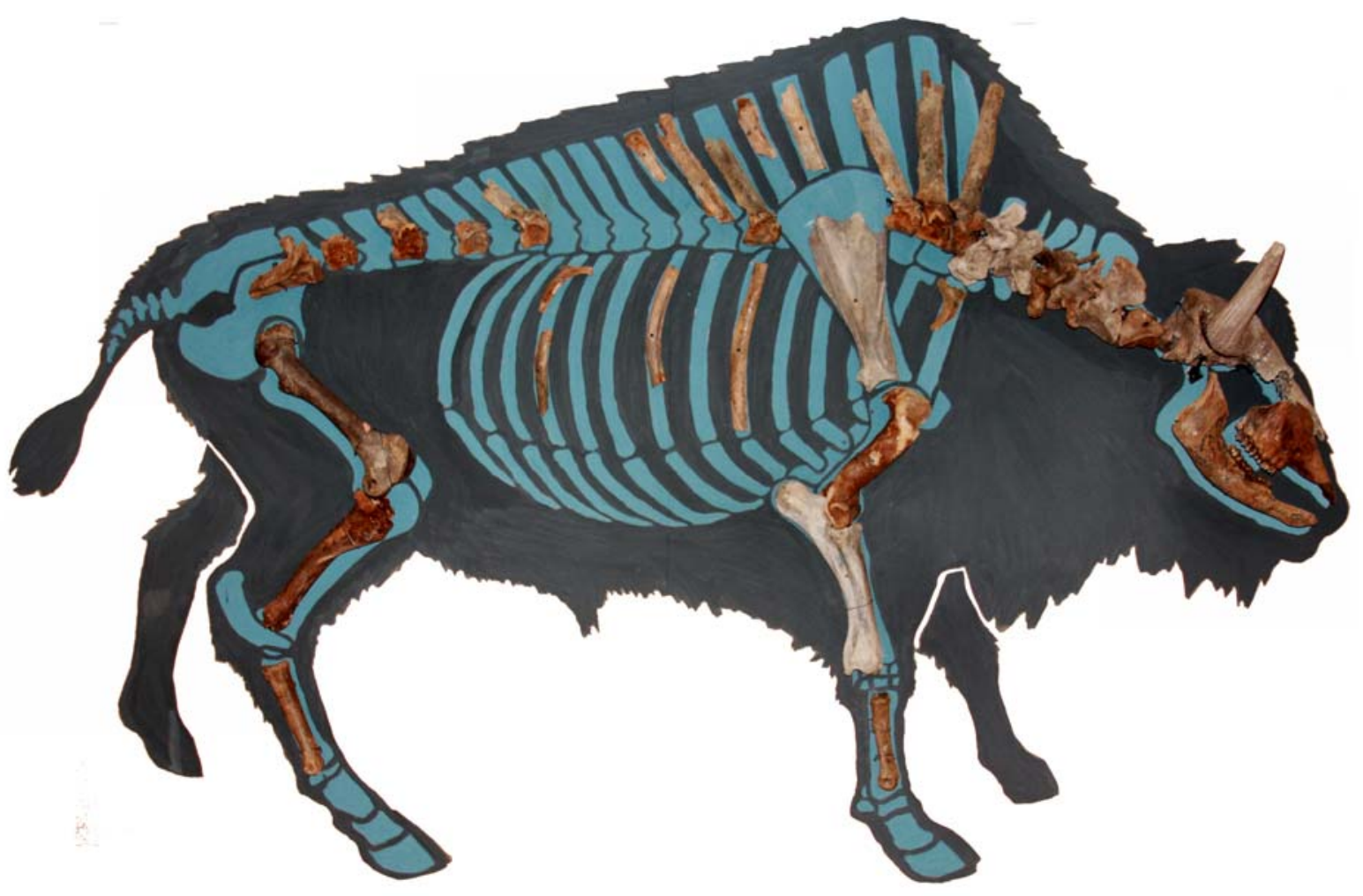

Fig. 6. The restoration of bison skeleton from Grigorievka (Pavlodar Region) in the Museum of Nature of the Arkalyk Pedagogical Institute (Kostanay Region).

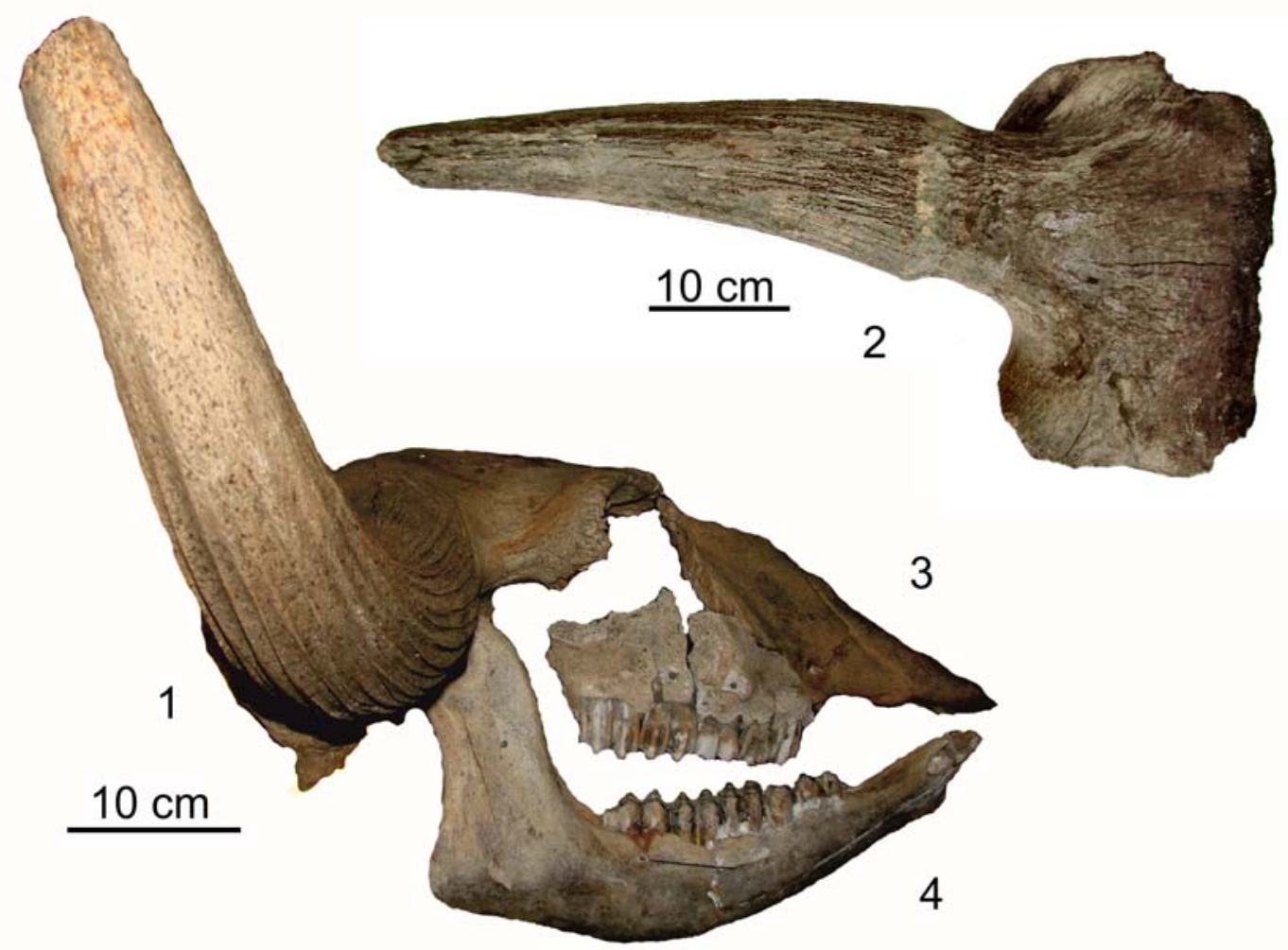

Fig. 7. The skull of a male bison (MP PGPI 1222-2) from Grigorievka (Pavlodar Region): 1 - fragment of the skull MP PGPI 1222-2, lateral view, 2 - fragment of the skull MP PGPI 1222-2, dorsal view, 3 — right facial bones MP PGPI 1222-1, lateral view, 4 - right mandibular ramus MP PGPI 1222-5, buccal view. 


\begin{tabular}{|c|c|c|c|c|c|c|c|c|c|c|c|c|c|c|c|c|c|c|c|}
\hline \multicolumn{2}{|c|}{ 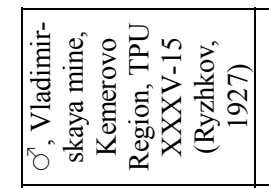 } & & & & $\underset{3}{\mathbb{f}}$ & & & & & & & \begin{tabular}{l}
$\infty$ \\
\multirow{2}{*}{}
\end{tabular} & $\vec{n}$ & ळे & & & & {$\left[\begin{array}{l}2 \\
\infty \\
\infty\end{array}\right.$} & 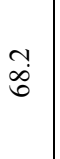 \\
\hline \multicolumn{2}{|c|}{ 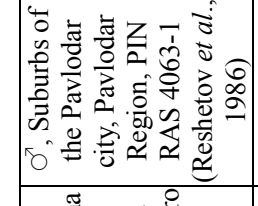 } & & 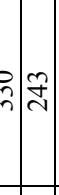 & & $\tilde{D}$ & 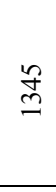 & & 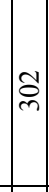 & ڤి & & in & $\stackrel{8}{8}$ & 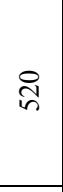 & हे & $\hat{a}$ & $\widehat{\Xi}$ & 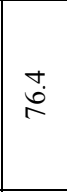 & $\stackrel{\infty}{\infty}$ & \&̊․ \\
\hline \multicolumn{2}{|c|}{ 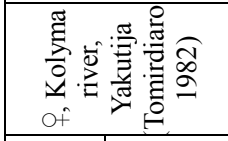 } & $\begin{array}{l}n \\
i n\end{array}$ & $\overrightarrow{0}$ & $\overline{6}$ & $\hat{\Omega}$ & 官 & ฮे & సิ & $=$ & & $\hat{\Xi}$ & $\stackrel{2}{6}$ & $\tilde{\Omega}$ & 1 & 1 & l & 1 & 1 & 1 \\
\hline \multirow{2}{*}{ 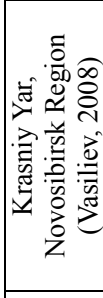 } & $\underset{0}{\stackrel{ \pm}{=}}$ & & 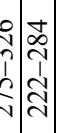 & ' & $\begin{array}{l}\text { ồ } \\
\text { dै } \\
\text { ते }\end{array}$ & $\begin{array}{l}0 \\
0 \\
0 \\
1 \\
8 \\
\infty\end{array}$ & । & 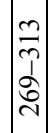 & 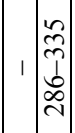 & & 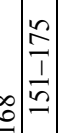 & 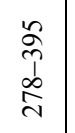 & \begin{tabular}{l}
$n$ \\
\multirow{2}{+}{} \\
$\stackrel{2}{2}$
\end{tabular} & $\begin{array}{l}n \\
0 \\
5 \\
\tilde{c} \\
m\end{array}$ & 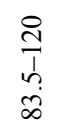 & & 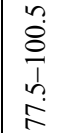 & 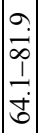 & $\begin{array}{l}m \\
2 \\
\text { ì } \\
\dot{8} \\
0\end{array}$ \\
\hline & 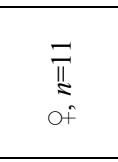 & & 5 & 1 & $\begin{array}{l}\stackrel{\leftrightarrow}{1} \\
\text { ì } \\
\text { ì }\end{array}$ & 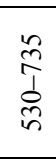 & 1 & f & 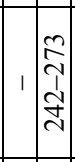 & & 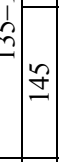 & 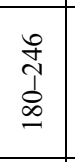 & 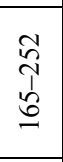 & 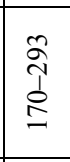 & $\begin{array}{l}\hat{n} \\
\hat{n}\end{array}$ & & \begin{tabular}{|c|}
$n$ \\
$n$ \\
0 \\
0 \\
$\infty$ \\
$\infty$ \\
$\infty$ \\
\end{tabular} & 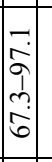 & 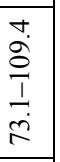 \\
\hline \multirow{3}{*}{ 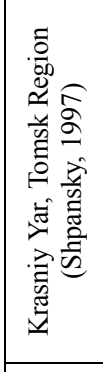 } & 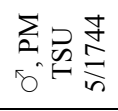 & & $\begin{array}{lll}1 & 1\end{array}$ & 1 & m & 1 & 1 & 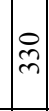 & 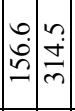 & & 它. & 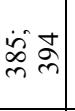 & $\stackrel{8}{\tilde{\delta}}$ & ঙิ & $\Xi$ & $\vec{\beth}$ & $\hat{\sigma}$ & $\left|\begin{array}{l}\infty \\
\infty \\
\vee\end{array}\right|$ & , \\
\hline & 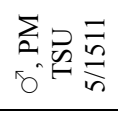 & 1 & \begin{tabular}{l|l}
$e$ \\
$\dot{v}$ & 1
\end{tabular} & 1 & 1 & 1 & 1 & 1 & 1 1 文 & 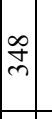 & 1 & ন & ৯े & $\stackrel{\infty}{~}$ & $\infty$ & 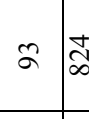 & $\stackrel{+}{\vec{\sigma}}$ & $\hat{i}$ & 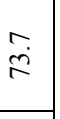 \\
\hline & 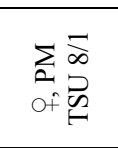 & 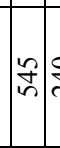 & \begin{tabular}{l}
$q$ \\
\hdashline
\end{tabular} & $\stackrel{\infty}{=}$ & ָె & 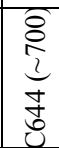 & $\stackrel{t}{0}$ & ¿̊ & $\stackrel{\overbrace{}}{A}$ & & 6 的 & ণ্ণ & $\stackrel{n}{a}$ & $\stackrel{8}{n}$ & 8 & $\therefore \infty$ & $\sigma$ & 文 & 8 \\
\hline \multirow{5}{*}{ 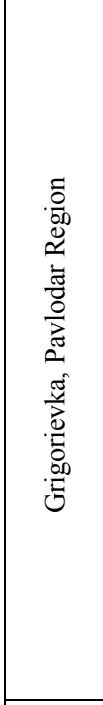 } & $\begin{array}{l}\sum_{0} \tilde{U} \\
0^{\circ} \approx \tilde{I}\end{array}$ & & \begin{tabular}{l|l}
1 & 1
\end{tabular} & $\stackrel{n}{n}$ & 1 & 1 & 1 & 1 & 1 & 5 & & $\stackrel{\circ}{m}$ & 品 & $\stackrel{\check{m}}{2}$ & 2 & 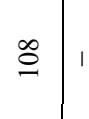 & $\begin{array}{l}\partial \\
\infty \\
\infty\end{array}$ & - & 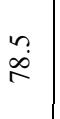 \\
\hline & $\underset{0}{\stackrel{\pi}{2}}$ & 1 & $\begin{array}{l}2 \\
\text { L } \\
\text { L }\end{array}$ & 1 & 'f & $\tilde{\infty}$ & 1 & $\cong$ & 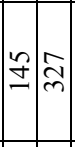 & প্লি & 8 & $\begin{array}{l}\hat{i} \\
\ddot{\hat{n}} \\
\dot{e}\end{array}$ & $\begin{array}{l}n \\
\tilde{n} \\
\tilde{m} \\
\tilde{n}\end{array}$ & 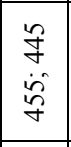 & $\sigma$ & $\approx \overbrace{\infty}^{\infty}$ & $\begin{array}{l}\infty \\
\dot{\alpha} \\
\alpha \\
\end{array}$ & \begin{tabular}{|c|}
0 \\
$\dot{2}$ \\
2 \\
$\dot{0}$ \\
2 \\
\\
\end{tabular} & 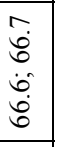 \\
\hline & 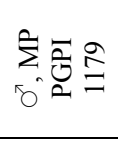 & 1 & $\begin{array}{c}c \\
n\end{array}$ & 1 & 帛 & $\stackrel{\ominus}{\stackrel{I}{I}}$ & 1 & ¿ి & & $\left|\begin{array}{l}0 \\
0 \\
\text { | }\end{array}\right|$ & 10 & $\frac{n}{m}$ & 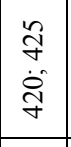 & \begin{tabular}{l|}
$n$ \\
$n$ \\
$\tilde{n}$ \\
$n$ \\
$n$
\end{tabular} & $\begin{array}{l}n \\
\alpha \\
\alpha \\
\alpha\end{array}$ & \begin{tabular}{l|l}
2 & $m$ \\
$\dot{\tilde{\sigma}}$ & $\sigma$
\end{tabular} & $\begin{array}{l}\stackrel{\circ}{-1} \\
\dot{0} \\
\infty\end{array}$ & 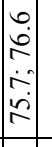 & $\begin{array}{l}\infty \\
\stackrel{\infty}{\circ} \\
\stackrel{n}{n}\end{array}$ \\
\hline & 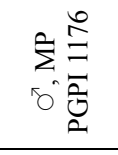 & 1 & & 1 & m & $\stackrel{n}{\varrho}$ & 1 & 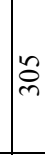 & & $\mid$ & $1 ?$ & $\stackrel{n}{m}$ & $\begin{array}{l}n \\
\dot{n} \\
\dot{n} \\
\dot{q}\end{array}$ & 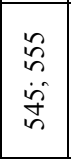 & $\begin{array}{l}\tilde{\delta} \\
\ddot{8}\end{array}$ & 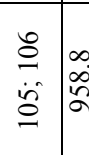 & 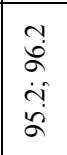 & 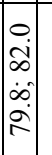 & $\begin{array}{l}t \\
0 \\
0 \\
i n \\
\dot{0}\end{array}$ \\
\hline & 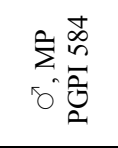 & $1 \%$ & & 1 & $\hat{m}$ & $\hat{n}$ & 1 & $\approx$ & & in & $1 \cong$ & $\stackrel{R}{m}$ & $\stackrel{n}{n}$ & $\begin{array}{l}n \\
n \\
\ddot{n} \\
n\end{array}$ & $\begin{array}{l}\stackrel{8}{\vdots} \\
\ddot{\tilde{\sigma}}\end{array}$ & $\equiv$ & $\begin{array}{l}0 \\
\dot{a} \\
i \\
i \\
a \\
\sigma\end{array}$ & $\left|\begin{array}{c}\infty \\
i \\
i \\
- \\
\dot{2} \\
\end{array}\right|$ & $\begin{array}{l}\infty \\
\dot{\pi} \\
\ddot{i} \\
\dot{b}\end{array}$ \\
\hline \multicolumn{2}{|c|}{ 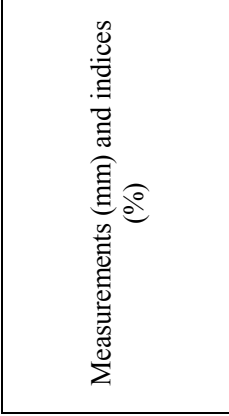 } & 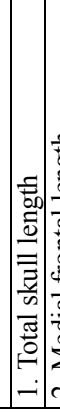 & 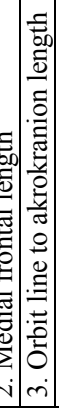 & 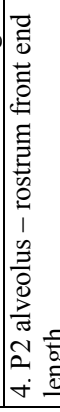 & 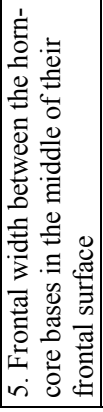 & 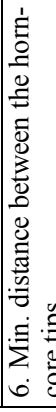 & 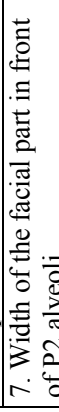 & 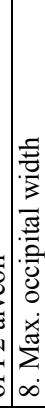 & 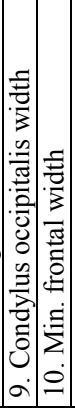 & & 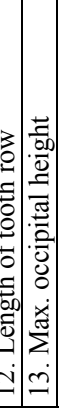 & 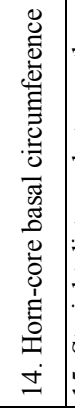 & 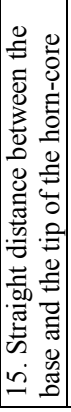 & 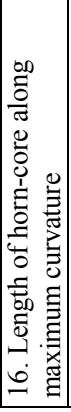 & 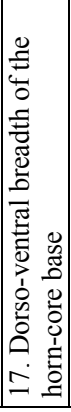 & 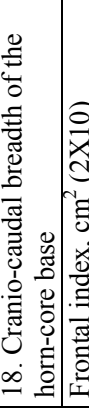 & 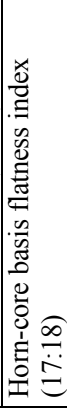 & 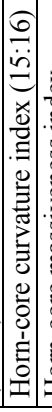 & 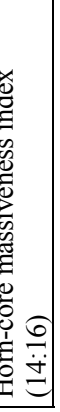 \\
\hline
\end{tabular}


Table 5. Mandible measurements of Bison priscus from various localities in Western Siberia.

\begin{tabular}{|c|c|c|c|c|}
\hline Measurements (mm) & $\begin{array}{l}\mathrm{O}^{7} \text {, Grigorievka, } \\
\text { Pavlodar } \\
\text { Region, MP } \\
\text { PGPI 1222-4 } \\
\text { and 5, left, right }\end{array}$ & $\begin{array}{c}\text { }, \text { Krasniy Yar, } \\
\text { Tomsk Region, PM } \\
\text { TSU 8/2a, b left, } \\
\text { right (Shpansky, } \\
\text { 1997) }\end{array}$ & $\begin{array}{c}n=39, \text { Krasniy Yar, } \\
\text { Novosibirsk Region } \\
\text { (Vasiliev, 2008) }\end{array}$ & $\begin{array}{l}\text { O', Vladimir- } \\
\text { skaya mine, } \\
\text { Kemerovo } \\
\text { Region, TPU } \\
\text { XXXVII-8 } \\
\text { (Ryzhkov, 1927) }\end{array}$ \\
\hline $\begin{array}{l}\text { Mandible length from rostrum to } \\
\text { mandibular angle }\end{array}$ & 457 & 428 & $407-492$ & - \\
\hline Diastema length & 145 & 125 & $121-154.5$ & - \\
\hline Length of $\mathrm{p} 2-\mathrm{m} 3$ along the alveoli & 165 & 168 & $156-190.2$ & 169 \\
\hline Length of the p2-4 row & 55 & 55 & $56-70.5$ & 64 \\
\hline Length of the m1-3 row & 111 & 110 & $100-124$ & 105 \\
\hline Oral height of the vertical ramus & - & 232 & $216-240$ & - \\
\hline Aboral height of the vertical ramus & 173 & - & $133-169$ & - \\
\hline $\begin{array}{l}\text { Height of the mandible in front of } \\
\text { p2 }\end{array}$ & 38.2 & 40 & $42.5-62.3$ & 58 \\
\hline $\begin{array}{l}\text { Height of the mandible between } \mathrm{m} 1 \\
\text { and } \mathrm{m} 2\end{array}$ & 66 & 66,68 & $55-77$ & 70 \\
\hline $\begin{array}{l}\text { Height of the mandible behind } \mathrm{m} 3 \\
\text { (maximum) }\end{array}$ & 82 & 70,72 & $73-95$ & 78 \\
\hline Greatest depth at $\mathrm{m} 3$ & 35 & 35 & $29.5-39.3$ & 37 \\
\hline Breadth of the procesus articularis & 50.3 & - & $42-62$ & - \\
\hline $\begin{array}{r}\text { Length/breadth p2 } \\
\text { p3 } \\
\text { p4 } \\
\text { m1 } \\
\text { m2 } \\
\text { m3 }\end{array}$ & $\begin{array}{c}13 / 10 \\
20 / 14 \\
24 / 16.2 \\
26 / 20 \\
33 / 21.5 \\
48.5 / 20.5 \\
\end{array}$ & $\begin{array}{l}12 / 9 \\
18 / 11 \\
23 / 16 \\
30 / 20 \\
34 / 22 \\
48 / 21\end{array}$ & $\begin{array}{c}11.3-14.5 / 8.8-10.6 \\
18-23.7 / 11.4-14.6 \\
20.3-28 / 12.7-17 \\
24.5-33 / 16.6-26.6 \\
27.6-37 / 17-22.4 \\
42-53.5 / 16-22.5\end{array}$ & $\begin{array}{c}- \\
- \\
- \\
25 / \\
33 / \\
46 /\end{array}$ \\
\hline
\end{tabular}

and ligaments are more resistant in the parts of the body with less muscle content. Muscles and ligaments decompose in water faster than skin, therefore, at the time of the deposition of the corpse, muscles had already been extensively macerated (Ochev et al., 1994). The mentioned change in colour of the containing clay around the bones was apparently a result of decomposition of soft tissues.

\section{Description of the Bison skeletons}

\section{Bison skeleton from Grigorievka}

Cranium (MP PGPI 1222-1 and 2). Three fragments have been preserved: right horn core with a part of frontal bone (Fig. 6,7), a fragment of left horn and right facial bones (maxillare with several teeth and premaxillare). Horn cores are relatively short and massive (Table 4), low-curved. The dorsal surface of the horn in its middle part is lower than the frontal surface. The horns do not project over the surface of the occiput, the tip of the horn is slightly elevated above the frontal surface. The surface of the frontal bone is low-arched. The lateral side of the rostral part of the premaxillare is slightly widened, which is typical for the steppe bisons (Flerov, 1979). The distance from the rear edge of the M3 to the front edge of the rostrum is $320 \mathrm{~mm}$. M1 is worn nearly to the root, M2 and M3 are worn to half, and premolars are $1 / 3$ worn. The length of the dental arch (P2-M3) is $151 \mathrm{~mm}$; the length of the M1-M3 is $88 \mathrm{~mm}$; the length of P2-P4 is $65 \mathrm{~mm}$. Teeth have the following lengths/widths: $\mathrm{P} 2=21 / 15.5 \mathrm{~mm}, \mathrm{P} 3=22.3$ / $23 \mathrm{~mm}, \mathrm{P} 4=18.5 / 25 \mathrm{~mm}, \mathrm{M} 1=24 / 27.5 \mathrm{~mm}, \mathrm{M} 2=30 /$ $27.5 \mathrm{~mm}, \mathrm{M} 3=35 / 28.2 \mathrm{~mm}$.

Both mandible rami (MP PGPI 1222-4 and 5) have been preserved (Table 5). Teeth are mostly worn to half; $\mathrm{m} 1$ is $2 / 3$ worn, $\mathrm{p} 2$ is only slightly worn. The distance from the front of the jaw to articular process is $490 \mathrm{~mm}$. The front of the $\mathrm{p} 2$ alveolus is $47.5 \mathrm{~mm}$ high.

The spine has been partially preserved: only 11 thoracic vertebrae have been preserved; atlas, $\mathrm{C}_{3}, \mathrm{C}_{4}$ and $\mathrm{L}_{1}$ are missing. The size of the vertebrae is average for $B$. priscus. Sacrum is completely preserved, but its wings are damaged.

Scapula, right (MP PGPI 1222-26) is severely damaged. The maximum axial length is $470 \mathrm{~mm}$, the length/ diameter of glenoid cavity is $84 / 69 \mathrm{~mm}$.

Humeri (MP PGPI 1222-27 and 28). The length of both bones is $370 \mathrm{~mm}$, diaphyses are $58 \mathrm{~mm}$ wide, proximal epiphyses are c111 (133 sin) mm wide and c118 (131 sin) $\mathrm{mm}$ in diameter, distal epiphyses of both bones are $106 \mathrm{~mm}$ wide and $106 \mathrm{~mm}$ in their maximum diameter.

Radii (MP PGPI 1222-29 and 30) (Table 6) are small in absolute size and massive. Their length is average for females from Krasniy Yar (Tomsk Region), and the relative width of epiphyses (indexes $2: 1 ; 6: 1$ ) is 

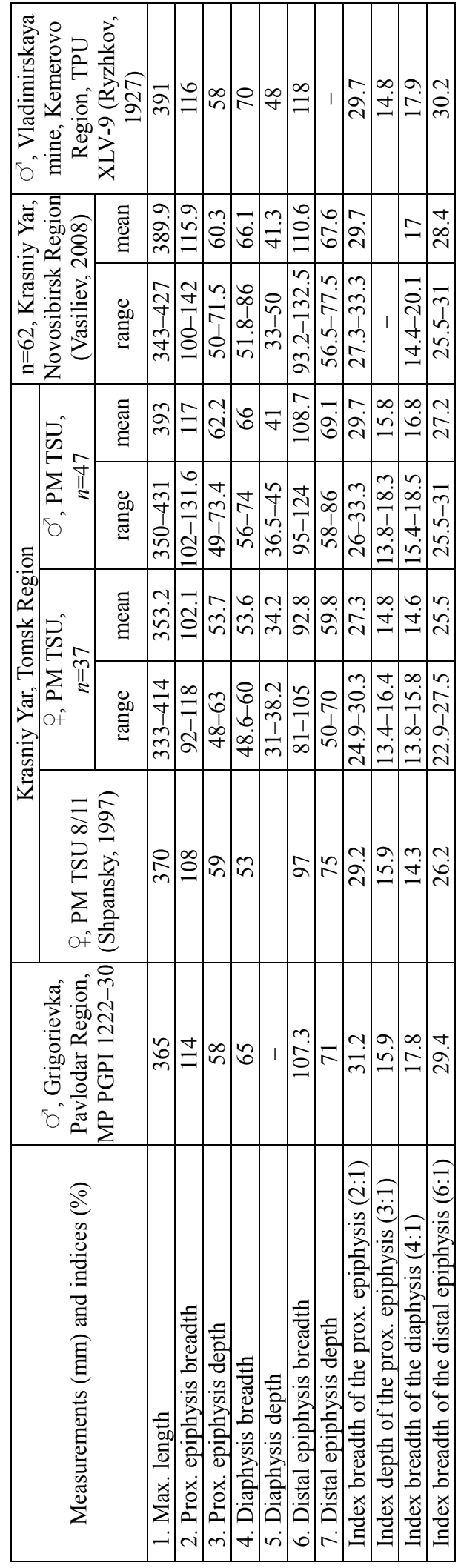

\begin{tabular}{|c|c|c|c|c|c|c|c|c|c|c|}
\hline \multirow{4}{*}{ 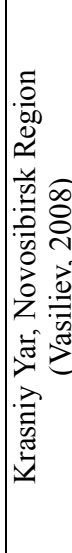 } & \multirow[b]{2}{*}{$0^{\circ}$} & 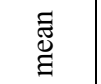 & $\stackrel{g}{\sim}$ & $\begin{array}{l}\infty \\
\infty \\
\infty\end{array}$ & $\vec{i}$ & in & $\begin{array}{l}\text { ণ } \\
\text { } \\
\text { లn }\end{array}$ & $\frac{n}{\sigma}$ & $\frac{9}{\partial}$ & $\hat{\sim}$ \\
\hline & & 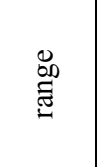 & 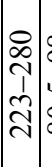 & $\begin{array}{l}\infty \\
0 \\
n \\
n \\
\infty \\
\infty\end{array}$ & 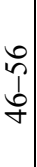 & \begin{tabular}{l}
$n$ \\
\multirow{0}{0}{} \\
$n$ \\
$n$ \\
$n$ \\
$n$
\end{tabular} & $\begin{array}{l}\bar{y} \\
\sigma \\
\bar{m}\end{array}$ & $\begin{array}{l}\frac{1}{8} \\
0 \\
1 \\
\infty\end{array}$ & 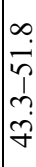 & 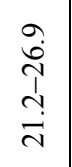 \\
\hline & & $\begin{array}{l}\underset{\mathbb{E}}{\Xi} \\
\stackrel{\Xi}{\Xi}\end{array}$ & $\mid \begin{array}{c}r \\
\dot{b} \\
\grave{\lambda}\end{array}$ & $\begin{array}{l}0 \\
\infty \\
\infty \\
\stackrel{0}{\infty}\end{array}$ & $\begin{array}{l}\infty \\
\dot{\sigma} \\
\dot{\sigma}\end{array}$ & $\begin{array}{l}7 \\
\dot{0} \\
+\end{array}$ & $\frac{0}{m}$ & $\overrightarrow{\dot{\infty}}$ & $\stackrel{\sim}{\mathscr{f}}$ & $\stackrel{n}{\circ}$ \\
\hline & $\begin{array}{c}\pi \\
= \\
0 \hat{f}\end{array}$ & 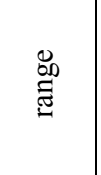 & 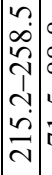 & $\begin{array}{l}\infty \\
\infty \\
\infty \\
\infty \\
\vdots \\
\vdots \\
\end{array}$ & $\begin{array}{l}0 \\
\dot{+} \\
\dot{b} \\
\infty \\
\dot{\dot{q}} \\
\dot{y}\end{array}$ & 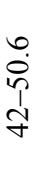 & $\begin{array}{l}n \\
\tilde{J} \\
\tilde{f} \\
n \\
\infty \\
\sim \\
\sim\end{array}$ & $\begin{array}{l}\infty \\
\infty \\
\infty \\
1 \\
\sim \\
\sim \\
\sim \\
\sim\end{array}$ & $\begin{array}{l}\infty \\
\dot{q} \\
\sim \\
\sim \\
\tilde{m}\end{array}$ & 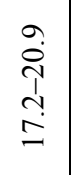 \\
\hline \multirow{5}{*}{ 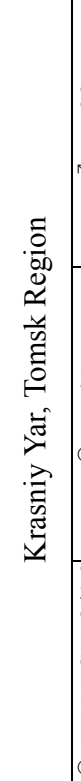 } & & $\begin{array}{l}\text { ॠี } \\
\stackrel{\Xi}{\Xi}\end{array}$ & $\mid \begin{array}{l}0 \\
\dot{O} \\
\stackrel{v}{2}\end{array}$ & $\begin{array}{l}\infty \\
\infty \\
\infty\end{array}$ & $\begin{array}{l}\infty \\
\dot{0} \\
i\end{array}$ & $\begin{array}{l}0 \\
\infty \\
\infty \\
n\end{array}$ & । & बू & 亲 & $\stackrel{m}{\sim}$ \\
\hline & $\begin{array}{c}\pi \\
= \\
0^{\circ}\end{array}$ & $\begin{array}{l}\infty \\
\infty \\
\text { 페 }\end{array}$ & 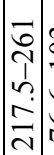 & $\begin{array}{l}2 \\
0 \\
1 \\
b \\
\dot{0} \\
r\end{array}$ & $\begin{array}{l}\mathcal{O} \\
0 \\
\mathcal{7} \\
\mathcal{f}\end{array}$ & $\begin{array}{l}\hat{0} \\
1 \\
0\end{array}$ & $\begin{array}{l}\infty \\
m \\
1 \\
\infty \\
m\end{array}$ & $\begin{array}{l}\infty \\
0 \\
1 \\
\infty \\
\infty\end{array}$ & $\begin{array}{l}n \\
i \\
n \\
n \\
m\end{array}$ & 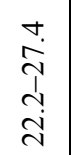 \\
\hline & $n$ & 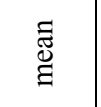 & 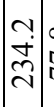 & 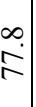 & $\overrightarrow{\dot{f}}$ & F & I & $\stackrel{1}{2}$ & $\frac{n}{\dot{\gamma}}$ & $\overrightarrow{\grave{d}}$ \\
\hline & $\begin{array}{c}\| \\
= \\
0 \hat{f}\end{array}$ & 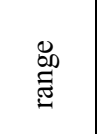 & 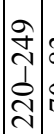 & $\begin{array}{c}\hat{n} \\
\infty \\
0 \\
2\end{array}$ & $\begin{array}{l}n \\
\vdots \\
y \\
n \\
\infty \\
\infty\end{array}$ & 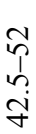 & I & $\begin{array}{l}\text { ì } \\
\text { ते }\end{array}$ & 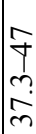 & $\begin{array}{l}\tilde{N} \\
\hat{\sigma} \\
\end{array}$ \\
\hline & \multicolumn{2}{|c|}{ 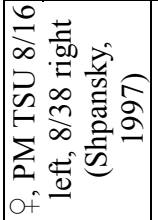 } & 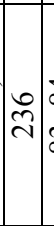 & \begin{tabular}{l}
\multirow{\infty}{\infty}{} \\
$\infty$ \\
$\infty$
\end{tabular} & $\begin{array}{l}\begin{array}{l}y \\
y \\
0 \\
\dot{y}\end{array} \\
0\end{array}$ & 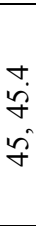 & 1 & $\begin{array}{l}\infty \\
\infty \\
\sim \\
\dot{\infty} \\
\dot{\infty}\end{array}$ & $\begin{array}{l}8 \\
f \\
f \\
f\end{array}$ & $\begin{array}{l}a \\
a \\
a\end{array}$ \\
\hline \multicolumn{3}{|c|}{ 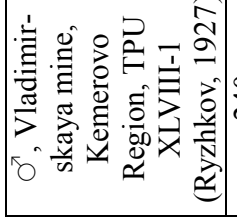 } & $\underset{\sim}{+}$ & 2 & & 8 & f & $\sigma$ & in & $\stackrel{0}{\sim}$ \\
\hline \multicolumn{3}{|c|}{ 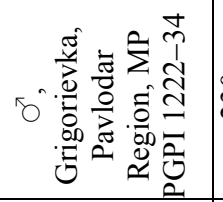 } & & $\bar{a}$ & & $\begin{array}{l}0 \\
\dot{n} \\
\end{array}$ & 1 & & $f$ & $\stackrel{+}{\mathrm{d}}$ \\
\hline \multicolumn{3}{|c|}{ 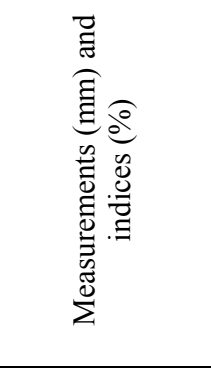 } & 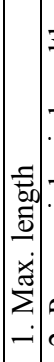 & 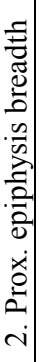 & 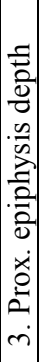 & 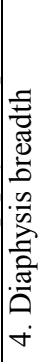 & 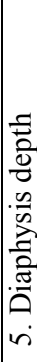 & \multicolumn{2}{|r|}{ 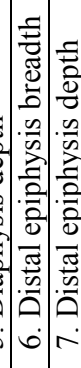 } & 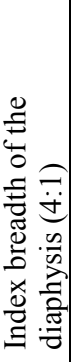 \\
\hline
\end{tabular}




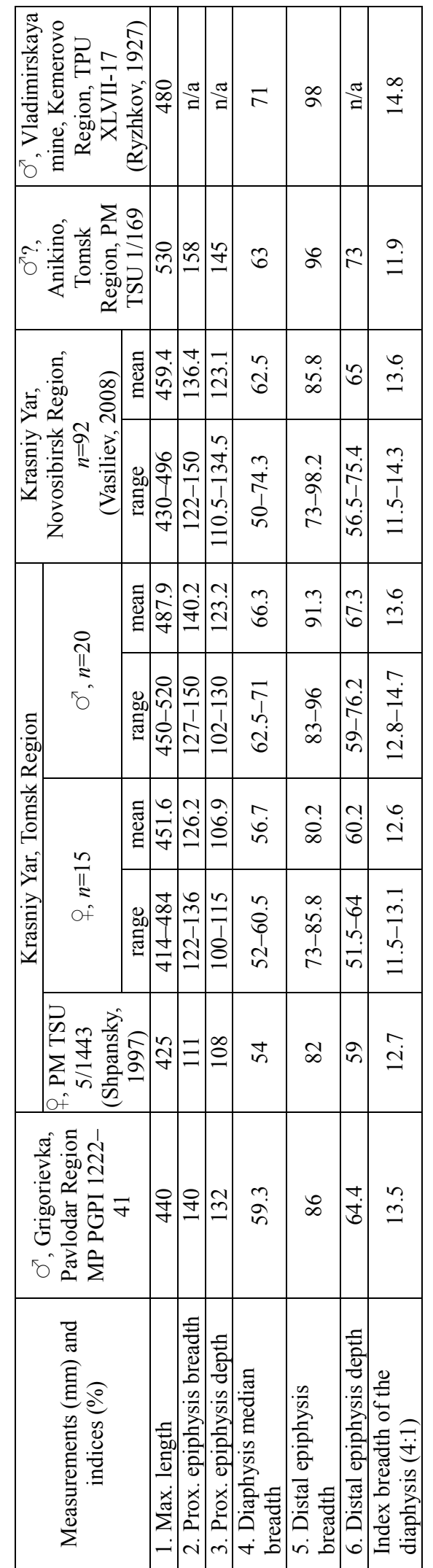

larger than average for the males from the same site. The width of the diaphysis middle part is close to average values for males, and its total relative width (indexes $4: 1)$ is greater than the average value for males.

Metacarpals 3+4 (MP PGPI 1222-33 and 34) are relatively short and not massive (Table 7). Comparing to the bones of Krasniy Yar (Tomsk Region) males, metacarpals $3+4$ of the Grigorievka skeleton are small and correlate with those of Grigorievka females. The proximal epiphysis is relatively large, and the distal epiphysis is narrow. The proximal epiphyses show signs of lump- and ridge-shaped periostosis. The width of the diaphysis in absolute and relative magnitude is at the minimum level for males and maximum level for females.

For the pelvic bones only the right ilium has been preserved.

Both femora (MP PGPI 1222-38 and 39) are damaged - the right one is missing the lower part and the left one - diaphysis. The left bone is c380 $\mathrm{mm}$ long, the diaphysis is $49 \mathrm{~mm}$ wide, the diameter of its head is $66 \mathrm{~mm}$. The distal epiphysis of the right bone is $133 \mathrm{~mm}$ wide and $151 \mathrm{~mm}$ in diameter.

Patella (MP PGPI 1222-40) is $78 \mathrm{~mm}$ long (high, in anatomical position), $65 \mathrm{~mm}$ wide and $50 \mathrm{~mm}$ in anterior-posterior width.

Tibiae (MP PGPI 1222-41 and 42) are short (Table 8 ), with wide epiphyses. The width of the diaphyses is significantly less than that of Krasniy Yar (Tomsk Region) males, but the diaphyseal width index is much higher than that of females and correlates well with indices for males.

\section{Bison skeleton from Krasniy Yar (Tomsk} Region)

Cranium (PM TSU 8/1, Fig. 8-1, 2, 3 and 4) is relatively small (Table 4), fronto-parietal sutures are obliterated. The facial part has a mechanical deformation and a displacement of the maxillare $2 \mathrm{~cm}$ to the right from sagittal plane. The cranium is relatively short and narrow in the front. Frontal index is $583 \mathrm{~cm}^{2}$. The facial part is short. The intermaxillare front ends do not have lateral widening of rostrums. The snout tapers on the front and it has a rounded edge. Flerov $(1965,1979)$ notes that the blade-shaped expansion of the rostral edge of intermaxillare is typical for the steppe bison forms. Modern wood Bison bonasus usually have narrow and rounded intermaxillare. The nasal bones are wedge shaped and slightly tapered rostrally. Their widest point is at the caudal section, which distinguishes them from broad and oval in the midpoint nasale of $B$. bonasus and approximates with $B$. bison. The facial part of the cranium is low in the maxillare section; the distance from eye socket bottom edges to M3 alveoli edges is much less than the length of the dentition. The width of the facial part in the front edge of the M3 is greater than the length of the dentition.

The surface of the forehead is almost flat with a small medial concavity between the eye sockets. The 


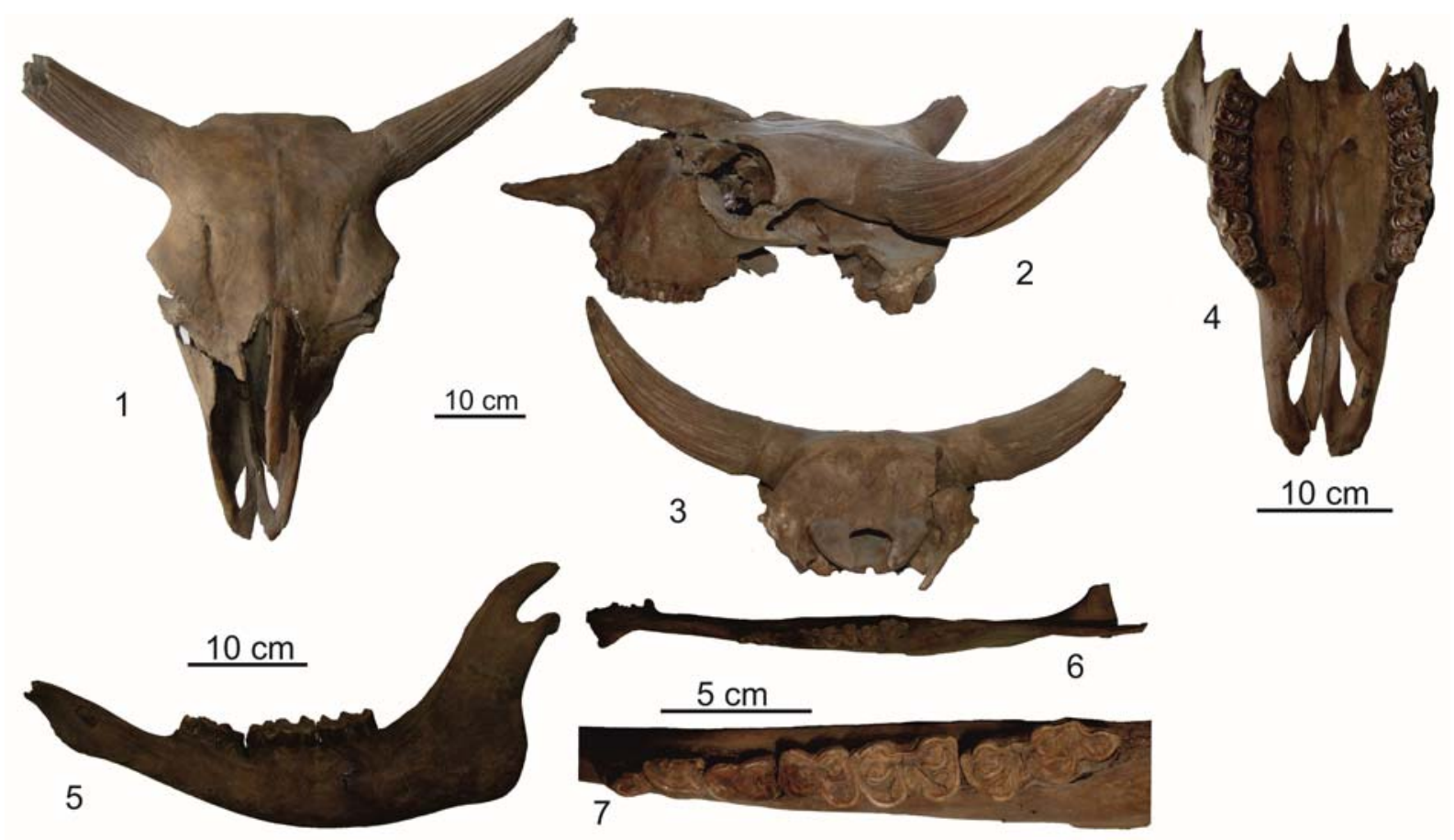

Fig. 8. The skull of a female bison (PM TSU 8/1) from Krasniy Yar (Tomsk Region): 1 - dorsal view; 2 - lateral view; 3 rear view. Left ramus of the mandible (PM TSU 8/2): 4 - maxillary teeth; 5 - buccal view; 6 - occlusal view; 7 dentition.

other two mild depressions are located at the front edges of the horn core bases, on each side of a small medial frontal protuberance. Sulcus supraorbitalis is wide, well defined and deep, with foramens and branches towards the tubular orbit. Foramina supraorbitale are large, lens-shaped. Eye sockets are slightly pointed laterally and anteriorly. Lacrimal bones are narrow, with a notch at the front and a narrow spike wedging in between nasale and maxillare. The distance from the lateral edge of the occipital condyle and lateral edge of the occipital crest is slightly longer than the length of $\mathrm{M} 2+3$, which might represent an archaic sign (Flerov, 1979). The distance from the rear edge of the M3 to the front edge of the rostrum is $297 \mathrm{~mm}$. M1 is worn nearly to the root, M2 and M3 are 2/3, and premolars are worn to half. The length of the dental arch (P2-M3) is 157 $\mathrm{mm}$; the length of the M1-M3 is $94 \mathrm{~mm}$; the length of $\mathrm{P} 2-\mathrm{P} 4$ is $63.5 \mathrm{~mm}$. Teeth have the following lengths/ widths: $\mathrm{P} 2=21.1 / 17.7 \mathrm{~mm}, \mathrm{P} 4=19.2 / 24.7 \mathrm{~mm}, \mathrm{M} 1=$ 25.3/28.7 mm, M2 = 30.6/33 mm, M3 = 30/33.3 mm.

Horn cores are pointed backwards (behind the occiput surface) and they diverge along the forehead surface, then they smoothly curve up. Horn cores are thin and gracile, with pointed ends, nearly circular at the base cross section (Table 4). Anterior-posterior diameter of the horn core base is slightly larger than the dorso-ventral one (flatness index (17:18) is $92 \%$ ), which is a characteristic of females (Gromova, 1935). The length of the cores is $275 \mathrm{~mm}$ chordwise and $350 \mathrm{~mm}$ at the largest curvature. The end of the right horn is broken, as such, the actual horn span apparently reached ca. $700 \mathrm{~mm}$ ( $644 \mathrm{~mm}$ by the broken end). The horn-core span for the modern B. bonasus equals 525-690 mm (Flerov, 1979). Longitudinal furrows and ridges ("rails") on the ventral side are deep and wide; they smooth down at the ends of the cores. The furrows on the dorsal side are narrow, with sharp pointed crests, and they extend to the end of the cores. A large number of vascular openings is located on the dorsal side of the distal parts of the horn piths.

Mandible (PM TSU 8/2a, b; Figs. 8-5, 6, 7). The horizontal rami are relatively thick, convex in the $\mathrm{m} 3$ area (Table 5); the height at the $\mathrm{m} 3$ area is $12 \mathrm{~mm}$ greater than the length of the $m 1+2$. The great height of the horizontal ramus indicates considerable pressure, which was put on the lower teeth during the mastication of a hard fodder. For the modern B. bonasus consuming soft foods, the height of the mandible horizontal branches equals the length of $\mathrm{m} 1+2$ (Flerov, 1979). Articular process (processus condyloideus) is long and wide, its width is twice as great as its length. The rear edge of the process hooks down, but it is not rounded, like the one in $B$. bonasus. The symphysis part is quite low, the ventral edge in the sagittal plane is keel-shaped. The incisor part of the symphysis gradually widens. The length of the symphysis is less than the length of $\mathrm{m} 2+3$. Canines are extensively worn and only represented by the $15-17 \mathrm{~mm}$ long roots. 


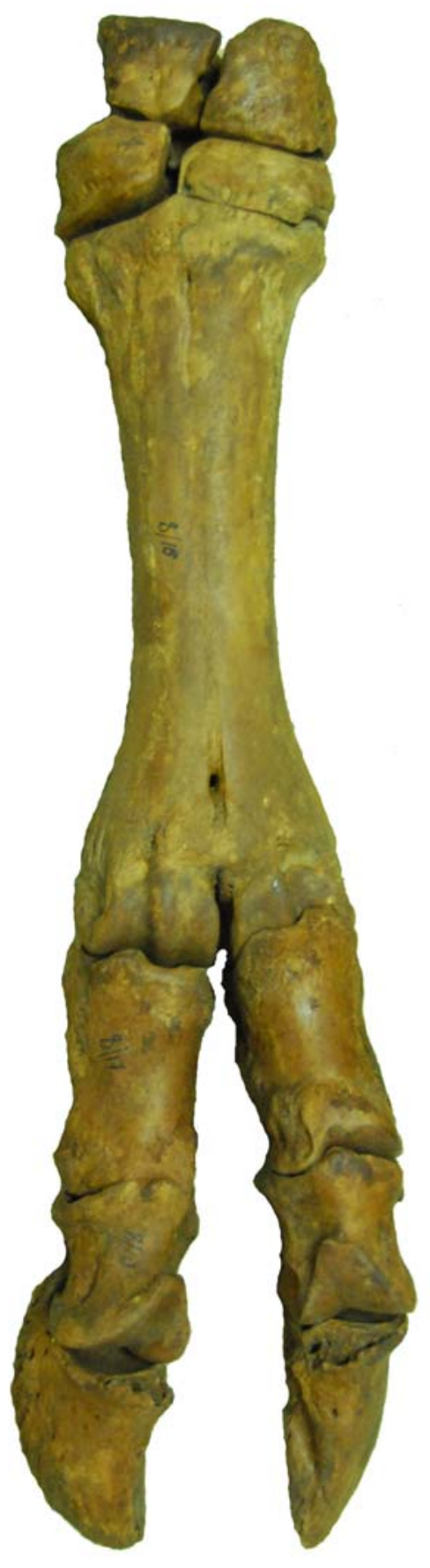

Fig. 9. Distal section of the right forelimb of a female bison from Krasniy Yar (Tomsk Region). Widely spaced toes are clearly visible.

Postcranial skeleton. All cervical vertebrae have been preserved, however, the spinous processes of axis to $\mathrm{C}_{7}$ have been bitten off. $\mathrm{C}_{6}$ and $\mathrm{C}_{7}$ bodies also have significant damages, with characteristic furrows from medium-sized rodent teeth. The total length of the neck is $50 \mathrm{~cm}$ (Fig. 5). The vertebrae are relatively small, with well-developed roughness on the transverse pro- cesses, which is related to the significant development of neck muscles. Atlas tuberculum ventrale is shifted towards the cranium as in typical $B$. priscus. In modern $B$. bonasus it is shifted towards the caudal edge of arcus ventralis (Reshetov \& Sukhanov, 1979).

Upper limb girdle. The total length of the preserved fragment of the left forelimb is $105 \mathrm{~cm}$, which is characteristic of large fossil bisons (Sokolov, 1971).

The proximal part of the humerus (PM TSU 8/10) is extensively damaged (gnawed); as such the total length of the bone is unknown; the distal epiphysis is $102 \mathrm{~mm}$ wide; the cross-section of block of labium laterale narrowing is $52 \mathrm{~mm}$.

Radius (PM TSU 8/11) is long, gracile and thin in the middle part, with wide, massive and rough epiphyses. The proximal epiphyseal diameter index overlaps in females and males, however, diaphysis index (4:1) is indicative of the sex for this individual (Table 6) - it lies at the level of average females from Krasniy Yar (Tomsk Region) and is significantly lower than that of males. Ulna is well adhered to the radius. The outline of the olecranon is sub-rectangle; olecranon is extensively gnawed.

Metacarpals 3+4 (PM TSU 8/16 and 8/38; Table 7). Similar to other bones of the limb, the size of metacarpal bones of the Krasniy Yar (Tomsk Region) bison correlates well by all parameters with that of females from Western Siberia. The diaphysis is thin, typical for B. priscus females. Epiphyses are massive, the width of the proximal epiphyses is at the level with the largest specimens. Fossa sinovialis goes far over the carpi $4+5$ surface facets. The ridge separating facets of the carpal articular surfaces is tall with sharp contours. The dorsal side of the canalis metacarpi distalis is oval, the palm side is expanded and rounded. Incisura intercondylaris is slightly extended, the blocks of the distal epiphysis are slightly inclined laterally from the sagittal plane. Such an inclination would have resulted in fingers being split apart, and the bearing surface of the front legs being large (Fig. 9). Ossa metacarpale 5 have been preserved; they are hook-shaped with massive proximal end and an oval facet for attachment of metacarpale $3+4$. They are $37 \mathrm{~mm}$ long and $15 \mathrm{~mm}$ wide.

Phalanx (Table 9). Two forelimb phalanges have been preserved; they are large, similar in shape to phalanges of $B$. priscus of Western Siberia.

Tibia (PM TSU 5/1443) is short, with narrow proximal epiphysis (Table 8). The distal epiphysis of the bone is relatively wide. The diaphysis is thin in absolute value, however its relative width is similar to the minimal width for males.

\section{Individual age and sex of the animals}

Grigorievka bison. A significant degree of tooth wear and obliterated fronto-pariental suture of the cranium indicate an age of the individual as ca. 10-12 years. Postcranial bones of the skeleton are relatively small, their dimensions are similar to those of average or large females from Krasniy Yar (Tomsk Region) and 
Table 9. Phalanx measurements of Bison priscus individuals from various localities in Western Siberia.

\begin{tabular}{|c|c|c|c|c|c|c|c|c|}
\hline \multirow[t]{2}{*}{ Measurements (mm) } & \multicolumn{4}{|c|}{$\begin{array}{c}\text { †, Krasniy Yar, Tomsk } \\
\text { Region, } \\
\text { forelimbs (Shpansky, 1997) }\end{array}$} & \multirow{3}{*}{$\begin{array}{l}\text { Krasniy Yar, } \\
\text { Tomsk Region, } \\
\quad \text { fore- and } \\
\text { hindlimbs, } n=93\end{array}$} & \multicolumn{2}{|c|}{$\begin{array}{l}\sigma^{7} \text {, Vladimirskaya mine, } \\
\text { Kemerovo Region } \\
\text { (Ryzhkov, 1927) }\end{array}$} & \multirow{3}{*}{$\begin{array}{c}\text { Krasniy Yar, } \\
\text { Novosibirsk } \\
\text { Region, } n=36 \\
\text { (Vasiliev, 2008) }\end{array}$} \\
\hline & \multicolumn{2}{|c|}{ left } & \multicolumn{2}{|c|}{ right } & & forelimbs & hindlimbs & \\
\hline Phalanx I & $\mathrm{I}_{3}^{*}$ & $\mathrm{I}_{2}$ & $\mathrm{I}_{2}$ & $\mathrm{I}_{3}$ & & right, $n=2$ & right, $n=1$ & \\
\hline Max. length & 80 & 79 & 79 & 80 & $71.6-95$ & 74 & 80 & $72.5-91.6$ \\
\hline Prox. epiphysis breadth & 44 & 44 & 44 & 43 & $42-51$ & 45 & 40 & $36.5-49.5$ \\
\hline Prox. epiphysis depth & 47 & 48.5 & 48 & 47 & $40-55$ & - & - & $38-56$ \\
\hline Diaphysis min. breadth & 40 & 38 & 37 & 39.5 & $33.8-48.7$ & - & - & $34-47$ \\
\hline Distal epiphysis breadth & 43 & 42 & 42 & 43 & $39-56$ & 47 & 41 & $35.3-49$ \\
\hline Distal epiphysis depth & 31 & 36 & 35.5 & 31 & $26-37$ & & - & $25.5-35$ \\
\hline Phalanx II & $\mathrm{II}_{3}$ & $\mathrm{II}_{2}$ & $\mathrm{II}_{2}$ & $\mathrm{II}_{3}$ & $\mathrm{n}=60$ & $\mathrm{n}=2$ & - & $n=34$ \\
\hline Max. length & 56 & 56 & 56 & 56 & $50-64$ & 50 & - & $46-58.8$ \\
\hline Prox. epiphysis breadth & 43 & 44 & 42 & 42 & $39-50$ & - & - & $39.3-54$ \\
\hline Prox. epiphysis depth & 45 & 46 & 46 & 43 & $37-52$ & - & - & $38-55$ \\
\hline Diaphysis min. breadth & 34 & 35 & 35 & 34 & $28.3-41$ & - & - & $31.5-44.8$ \\
\hline Distal epiphysis breadth & 40 & 39 & 40 & 39 & $31-45.6$ & - & - & $33.7-44.8$ \\
\hline Distal epiphysis depth & 38.5 & 40 & 40 & 38.5 & $33.7-48$ & - & - & $35-44.3$ \\
\hline Phalanx III & $\mathrm{III}_{3}$ & $\mathrm{III}_{2}$ & $\mathrm{III}_{2}$ & $\mathrm{III}_{3}$ & $\mathrm{n}=48$ & $\mathrm{n}=2$ & $\mathrm{n}=1$ & $\mathrm{n}=45$ \\
\hline Ventral length (max.) & 99 & 104 & 104 & 98 & $73-109$ & 90 & 76 & $75-104$ \\
\hline Dorsal length & 78 & 79 & 80 & 76 & $60-86.5$ & 66 & 60 & $58-80.9$ \\
\hline Articular surface breadth & 50 & 49 & 49 & 49 & $31-54$ & - & - & $27-41.5$ \\
\hline Height bones (max.) & 50 & 50 & 49 & 50 & $41-60$ & - & - & $45-68.3$ \\
\hline
\end{tabular}

*Numbers indicate phalanx (I, II or III) and toe (2 or 3$)$.

to those of small males (Tables 6-8). We, however, defined the individual from Grigorievka as male on the basis of large horn cores and massive (large relative diaphyseal width) radii, metacarpale $3+4$ and tibia. For this individual, sexual dimorphism appears more distinctively on radii and tibiae.

Krasniy Yar (Tomsk Region) bison. Sharp ends of horn cores and unclosed vascular openings indicate a continuing growth of horn piths and their shells. However, deep and wide furrows on the horn cores, obliterated frontal sutures and postcranial bones, as well as extensively worn P4, M1 and lower teeth indicate that the individual was not less than 15 years of age. The individual is undoubtedly female, which is evident from the small size of the skull (frontal index (2X10) is 583 $\mathrm{cm}^{2}$ ) and short and thin horns. Thin diaphysis of radius and metacarpale $3+4$ are also indicative of a female.

\section{Discussion}

Age and sex attribution of the studied individuals

The compared bison individuals have nearly completely obliterated cranial sutures, middle and advanced stage of tooth wear and complete fusion of long bone epiphyses, which is suggestive of the age of these individuals as adults of more than ten years old.

Sex attribution of the Grigorievka skeleton is rather complicated - the dimensions of the preserved part of skull and limb bones do not allow definite sex determination. The skull of the Grigorievka skeleton has been very poorly preserved, which makes it impossible to compare it with the skull of the Krasniy Yar (Tomsk Region) skeleton, as well as other remains from Western Siberia. However, the available parameters of horn cores approximate the Krasniy Yar (Tomsk Region) individual with males. The most indicative feature is the massive size of the horn core base, which is at the level of average Grigorievka males and significantly exceeds the values for the Krasniy Yar (Tomsk Region) and Krasniy Yar (Novosibirsk Region) females (Table $4)$. The horn core curvature index $(15: 16)$ of the Grigorievka skeleton is in opposite much larger than that of male skulls from this and other sites, and is at the average level with indexes for females from Krasniy Yar (Novosibirsk Region). For the Krasniy Yar (Tomsk Region) skull, the horn core massiveness index (14:16) is lower than those for females, which is a result of their advanced oblongness. The skulls from a number of Western Siberian sites have demonstrated that, for the majority of measurements, the absolute values for males and females are well-differentiated (Table 4). From the obtained index values, the frontal index (2X10) appears the most reliable for the sex determination. The horn-core massiveness index (14:16) requires further research. The horn-core base flatness index (17:18) and horn-core curvature index (15:16) are largely overlapping.

\section{Geological age of the studied individuals}

All bison skeletons discovered in the South-East of the Western Siberia were located in alluvial sands. Their sex and geological age vary. Apparently, the 


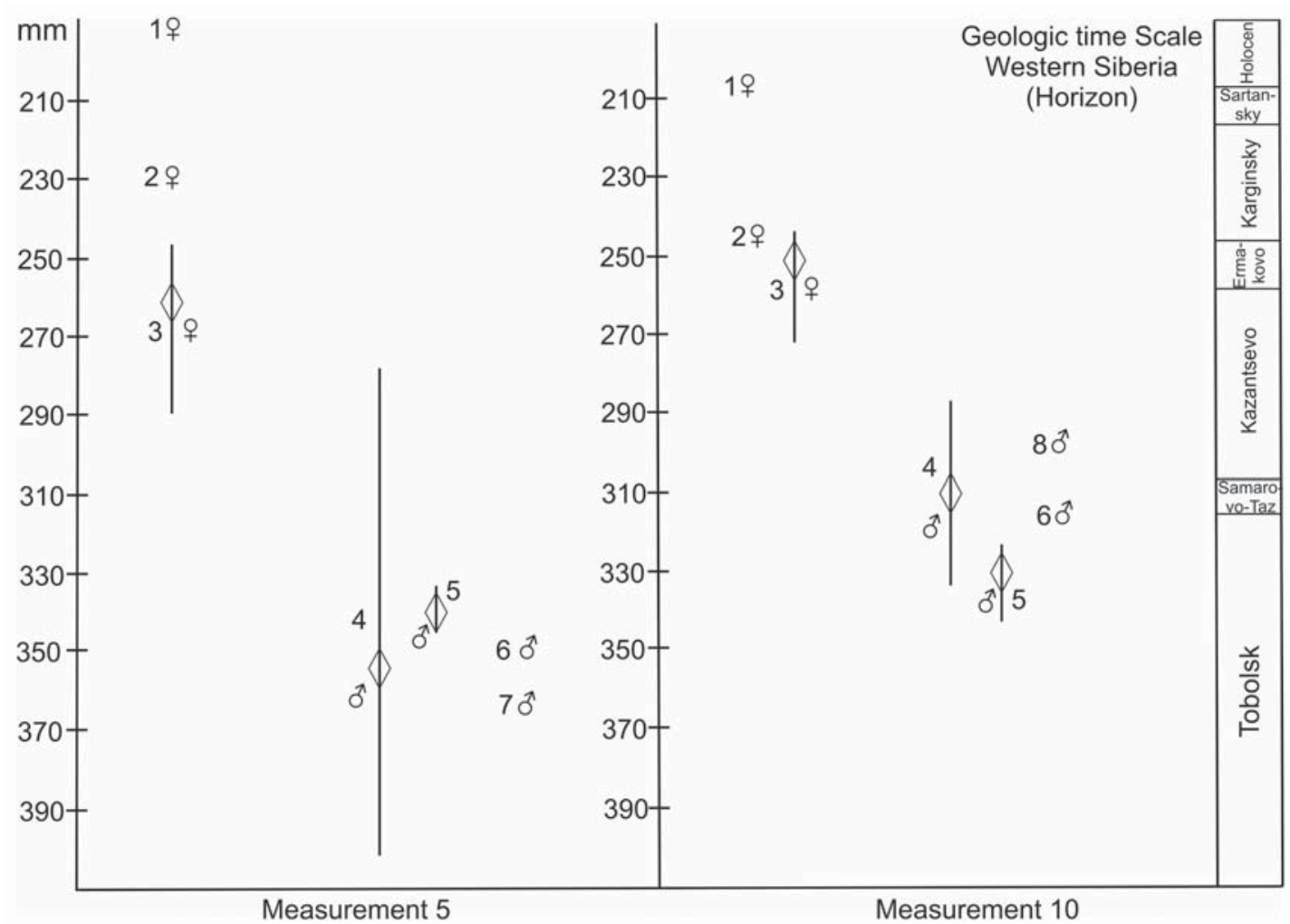

Fig. 10. Measurements (5 and 10 in Table 3) of male and female bison skulls from the Siberian sites of various geological age: 1 - Kolyma (Tomirdiaro, 1982); 2 - Krasniy Yar (Tomsk Region, PM TSU 8/1); 3 - Krasniy Yar, females (Novosibirsk Region; Vasiliev, 2008); 4 - Krasniy Yar, males (Novosibirsk Region; Vasiliev, 2008); 5 — Grigorievka (Pavlodar Region); 6 - Krasniy Yar (Tomsk Region, PM 5/TSU 1744); 7 — Pavlodar (PIN RAS 4063-1); 8 — Krasniy Yar (Tomsk Region, PM TSU 5/1511). Average values for the samples are marked with diamonds. Geologic time periods are not to scale.

Grigorievka skeleton belongs to the beginning of Middle Neopleistocene (Tobolsk Horizon; MIS 9-11) as suggested by joint finding of Elasmotherium sibiricum, Mammuthus trogontherii chosaricus, Camelus knoblochi, Saiga tatarica, large numbers of Megaloceros giganteus ruffi remains, and other species (Table 1). The co-existence of those species was characteristic of Irtysh faunal complex of Western Siberia (Shpansky, 2009). Direct AMS radiocarbon dating was not possible in this case because of the degradation of bone collagen (Table 3).

Together with the bison skeleton from the Vladimirskaya mine, two $\mathrm{m} 2$ teeth from the same mammoth individual have been found (data from Ryzhkov, 1927). Morphological characteristics of these teeth (enamel thickness of $2 \mathrm{~mm}$, lamellar frequency of 9 per $10 \mathrm{~cm}$ and other) correspond with those of Mammuthus primigenius Blumenbach. Furthermore, taking into account facies features of bearing deposits, it is possible to suggest the age of these finds as second half to Late Neopleistocene (possibly Karginsky Horizon; MIS 3), which is close to the geological age of the bison skeleton from Krasniy Yar (Tomsk Region).

AMS radiocarbon dates have been obtained for two other skulls from Krasniy Yar (Tomsk Region). Both skulls are male, but their morphology is slightly differ- ent. The smaller skull (PM TSU 5/1511) has less massive horns bent forward more extensively. Its ${ }^{14} \mathrm{C}$ age (40520-43490 cal BP, UBA-25870) is close to that of a female bison (PM TSU 8/1) (44620-49820 cal BP, UBA-21202) (Table 3). A number of measurements of the skull (PM TSU 5/1511) are similar to those of a male skull from the Vladimirskaya mine. Skull (PM TSU 5/1744) is larger with massive widely set and slightly curved horns. Radiocarbon date for this individual is outside the sensitivity of the method ( $>44926$ BP, UBA 25872). The dimensions of this skull are very similar to large skulls (MP PGPI 584, 1176 and 1179 and one individual without ID) from Grigorievka (Table 4). We can assume that the skull from the Krasniy Yar (PM TSU 5/1744), as well as remains of rhinoceros Stephanorhinus kirchbergensis (Shpansky \& Billia, 2012) have been re-positioned from more ancient sediments (possibly beginning of Middle Neopleistocene, Tobolsk Horizon). Generally, this preliminary data suggests that Middle Neopleistocene male bisons of Western Siberia were somewhat larger than males of the second half of the Late Neopleistocene (Fig. 10).

The comparison of female skulls from heterochronous deposits of Siberia reveals the gradual decrease in size of the animals, from the large individuals of the beginning of the Late Neopleistocene (MIS 5; Krasniy 

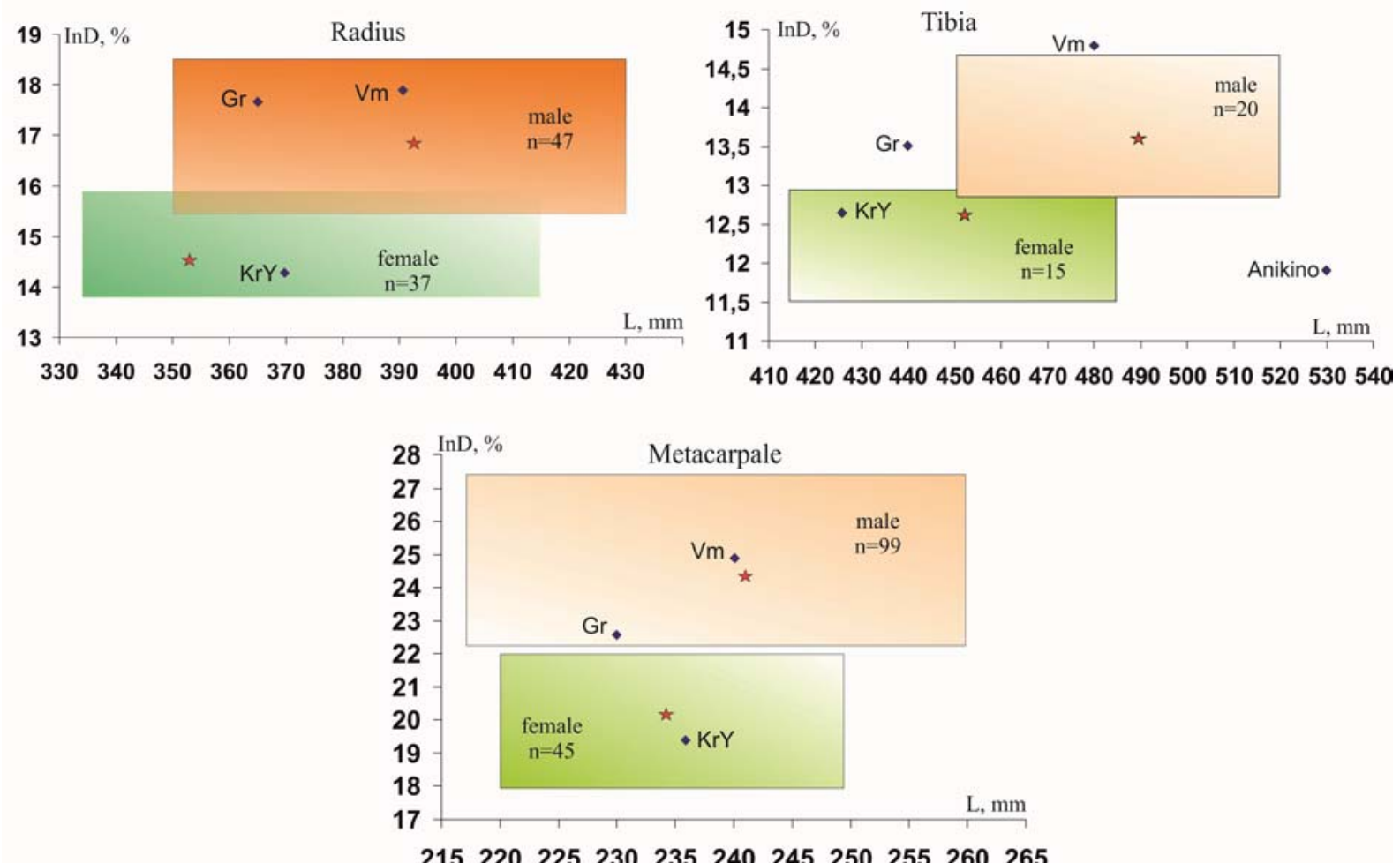

Fig. 11. The ratio of diaphysis index (InD) to the length of $(\mathrm{L})$ radius, metacarpal and tibia bones of Bison priscus from Western Siberia: KrY — Krasniy Yar; Gr — Grigorievka; Vm — Vladimirskaya mine; star — mean vales for males and females in Krasniy Yar (Tomsk Region).

Yar, Novosibirsk Region), towards an intermediate position of the skull from deposits of Karginsky Horizon (45000 years, MIS 3; Krasniy Yar, Tomsk Region) and, finally, to the smaller skull from Early Holocene of Yakutia (Fig. 10). The female skull from the Kolyma River ( 10000 years; Tomirdiaro, 1982) is relatively small, with very short horns (the distance between the horn tips is $379 \mathrm{~mm}$; Table 4). The horn-span of the mummified "Yukagir bison" male (Yakutia; 9310 \pm 45 BP; GrA-53290) was 710 mm (Boeskorov et al., 2013), which is distinctively smaller than that of the Late Neopleistocene males. At the moment, there is no data for the female skulls of the Middle Neopleistocene from Western Siberia. Further radiocarbon dating of a significant number of skulls with various morphological features is required. A large number of bison skulls of both sexes are available from the Krasniy Yar site (Novosibirsk Region; Vasiliev, 2008) however, at present these have not been radiocarbon dated. According to S.K. Vasiliev (2008), the above skulls and the major part of the postcranial remains presumably belongs to Eemian, and the Kazantsevo Horizon of the Siberian stratigraphic scale (MIS 5).

Morphological analysis of the postcranial skeleton

Skeletons from Krasniy Yar (Tomsk Region) and Grigorievka have similar lengths of long bones: their absolute values are comparable with those for females from major sites of Western Siberia (Tables 6-8). For the skeleton from the Vladimirskaya mine, all dimensions of long bones are at the level of medium or higher for males. The long bones from the major sites of Western Siberia (Krasniy Yar of Tomsk Region and Krasniy Yar of Novosibirsk Region) are considerably overlapping in the extreme values of most of the parameters in males and females. The values for the maximum length of radial bone appear specifically similar. The minimal overlap was observed for the absolute values of the diaphysis middle (Fig. 11). The mean values for males and females very well differentiate in this parameter - the Krasniy Yar (Tomsk Region) female and Grigorievka male values are average for respectively females and males from the Krasniy Yar (Tomsk Region) site. The radius diaphysis width of the Vladimirskaya mine male is much larger than the average for males. A clear sex attribution for the analysed skeletons can be obtained from the relative diaphysis width. For the Krasniy Yar (Tomsk Region) female this value is slightly less than the average for females, and for males from Grigorievka and Vladimirskaya mine they are significantly higher than the average for males. Similar pattern can be observed on metacarpals and tibia of the analysed skeletons.

Based on the size of the limb parts, the withers height of analysed skeletons can reach $180-185 \mathrm{~cm}$ for 
the Krasniy Yar (Tomsk Region) individual, and no more than $180 \mathrm{~cm}$ for the Grigorievka one. The height of the skeleton from the Vladimirskaya mine was about $190 \mathrm{~cm}$.

The Krasniy Yar (Tomsk Region) female had very large phalanx III (at the level of maximum for the WestSiberian bisons, Table 9) and the considerable width of the distal parts of radii and metacarpale (index 6:1). Its toes were extensively spread to the sides (Fig. 9), which indicates a large foot bearing surface for the forelimbs and suggests wet soft soils as a possible habitat of the animal. It is also possible that the animal was adapted to snow hoofing in search for food. For the Grigorievka skeleton phalanx have not been preserved, however, the robustness of the metacarpale distal epiphysis (index $6: 1)$ suggests a large area of phalanx III and forelimbs in general. Coupled with a relatively small head and modest body height, such wide hooves may indicate the spread of this animal in floodplains with soft soils and excess of shrubs and trees, rather than in the open steppe landscapes. The anatomical positioning of the bones of this individual confirms its death on the river bank and unreworked burial of the body.

\section{Conclusions}

The results of the radiocarbon dating of bison skeletons from Krasniy Yar (PM TSU, 8/1-53) and Grigorievka (MP PGPI 1222) have made substantial adjustments to the interpretation of stratigraphy of the Quaternary deposits in the sites of Krasniy Yar (Tomsk Region) and Grigorievka, as well as to the time of formation of the large mammal burials.

The morphological analysis of the bison skeletons from the Western Siberia has demonstrated that sex differentiation based on isolated bones can be very complicated and ambiguous. Male and female skulls have quite clear dimensional differences for most measurements. The dimensions of the skulls of different geological ages reflect the gradual decrease in size of animals during the Late Neopleistocene.

The comparison of morphometric data from the postcranial skeleton does not always clearly indicate the sex of the individual. The studies of the large samples of bison long bones from the major sites of Western Siberia have shown significant overlap of the absolute values. The most clear sexual dimorphism appeared on the relative width of the diaphysis of radius, tibia and metacarpale. Sex ratio $\left(+: \bigcirc^{7}\right)$ for the Krasniy Yar (Tomsk Region) sample is $37: 47(1: 1.27)$ by radius, 45:99 (1:2.2) by metacarpale, and 15:20 (1:1.33) by tibia.

The obtained morphometric data on male bison skeletons of Middle-Late Neopleistocene suggests the presence of two bison forms, related to two different habitats. Apparently, the larger form inhabited open steppe dry landscapes, and a smaller form inhabited humid river brushwood floodplains.
ACKNOWLEDGEMENTS. The research has been performed within the framework of the State Program of the Russian Federation No. 6.657.2014/K. This study was supported by D.I. Mendeleev Academic Foundation, the Tomsk State University in 2015 (research grants Nos. 8.1.25.2015 and 8.1.80.2015).

\section{References}

Boeskorov G.G., Protopopov A.V., Mashchenko E.N., Potapova O.P., Kuznetsova T.V., Plotnikov V.V., Grigoryev S.E., Belolyubskii I.N., Tomshin M.D., Shchelchkova M.V., Kolesov S.D., van der Plicht J. \& Tikhonov A.N. 2013. New findings of unique preserved fossil mammals in the permafrost of Yakutia // Doklady Biological Sciences. Vol.452. P.291-295.

Bronk Ramsey C., Higham T., Bowles A. \& Hedges R. 2004. Improvements to the pretreatment of bone at Oxford // Radiocarbon. Vol.46. No.1. P.55-63.

Brown T.A., Nelson D.E., Vogel J.S. \& Southon J.R. 1988. Improved collagen extraction by modified Longin method // Radiocarbon. Vol.30. No.2. P.171-177.

DeNiro M.J. 1985. Postmortem preservation and alteration of in vivo bone collagen isotope ratios in relation to palaeodietary reconstruction // Nature. Vol.317. No.6040. P.806-809.

Flerov K.K. 1965. [Comparative craniology of recent representatives of the genus Bison] // Bulletin of Moscow Society of Naturalists. Series Biological. Vol.70. No.1. P.40-54 [in Russian].

Flerov K.K. 1979. [Systematics and evolution] // Sokolov V.E. (ed.). Zubr. Moscow: Nauka. P.9-127 [in Russian].

Gromova V.I. 1935. [The fossil bison (Bison priscus Bojanus) of the USSR] // Proceedings of the Zoological Institute USSR. Vol.2. No.2-3. P.77-205 [in Russian].

Ochev V.G., Yanin B.T. \& Barskov I.S. 1994. [Methodological Guide for the Vertebrates Taphonomy]. Moscow: Moscow University Press. 143 p. [in Russian].

Reimer P.J., Bard E., Bayliss A., Beck J.W., Blackwell P.G., Bronk Ramsey C., Buck C.E., Cheng H., Edwards R.L., Friedrich M., Grootes P.M., Guilderson T.P., Haflidason H., Hajdas I., Hatté C., Heaton T.J., Hoffmann D.L., Hogg A.G., Hughen K.A., Kaiser K.F., Kromer B., Manning S.W., Niu M., Reimer R.W., Richards D.A., Scott E.M., Southon J.R., Staff R.A., Turney C.S.M. \& van der Plicht J. 2013. IntCal13 and Marine13 radiocarbon age calibration curves 0-50,000 years cal BP // Radiocarbon. Vol.55. No.4. P.1869-1887.

Reshetov V.Yu., Dmitrieva E.L. \& Vasiliev Yu.M. 1986. A fossil Bison from the Moscow Region and the geological conditions of its locality // Quartärpaläontologie. Vol.6. P.173-183.

Reshetov V.Yu. \& Sukhanov V.B. 1979. [Postcranial skeleton] // Sokolov V.E. (ed.). Zubr. Moscow: Nauka. P.142195 [in Russian].

Rusanov B.S. 1975. [Fossil Bisons of Yakutia]. Yakutsk. 143 p. [in Russian].

Ryzhkov P.M. 1927. [Elephas primigenius Blum. and Bison priscus H.v. Meyer from Kemerovo mine, Tom River] // Izvestiya Sibirskogo Tekhnologicheskogo Instituta. Vol.47. No.3. P.54-70 [in Russian]. 
Shpansky A.V. 1997. [Find of fossil Bison in Tomsk Ob River area] // Bulletin of Moscow Society of Naturalists. Series Geological. Vol.72. No.1. P.46-52 [in Russian].

Shpansky A.V. 2006. Quaternary mammal remains from the Krasniy Yar locality (Tomsk region, Russia) // Quaternary International. Vol.142-143. P.203-207.

Shpansky A.V. 2009. [Stratigraphic location of the Irtysh faunal complex] // Fundamental'nye Problemy Kvartera: Itogi Izucheniya i Osnovnye Napravleniya Dal'neishikh Issledovanii. Materialy VI Vserossiiskogo Soveshchaniya po Izucheniyu Chetvertichnogo Perioda. Novosibirsk. P.640-643 [in Russian].

Shpansky A.V. 2011. [Giant deer Megaloceros giganteus (Blum.) (Mammalia, Artiodactyla) from Neopleistocene of south-east Western Siberian Plain] // Bulletin of Moscow Society of Naturalists. Series Geological. Vol.86. No.1. P.18-30 [in Russian].

Shpansky A.V. 2014. Juvenile remains of the "woolly rhinoceros" Coelodonta antiquitatis (Blumenbach 1799) from the Tomsk Priob'e area (Southeast Western Siberia) // Quaternary International. Vol.333. P.86-99.

Shpansky A.V. \& Billia A.E.A. 2012. Records of Stephanorhinus kirchbergensis (Jager, 1839) (Mammalia, Rhinocerotidae) from the Ob' River at Krasniy Yar (Tomsk region, southeast of Western Siberia) // Russian Journal of Theriology. Vol.11. No.1. P.47-55.

Shpansky A.V. \& Pecherskaya K.O. 2006. [Taphonomic analysis of a bison's skeleton site near Krasniy Yar (Krivosheinsky District, Tomsk Region)] // [Late Cenozoic Geological History of the North of the Arid Zone]. Rostov-on-Don. P.268-273 [in Russian].

Shpansky A.V., Peresvetov G.Yu., Aliyasova V.N. \& Titov S.V. 2007. [New findings of the Quaternary mammals remains in Pavlodar Priirtysh area] // Bulletin of Commission for Study of the Quaternary. Vol.67. P.97-99 [in Russian].

Slota J.P., Jull A., Linick T. \& Toolin L. 1987. Preparation of small samples for ${ }^{14} \mathrm{C}$ accelerator targets by catalytic reduction of CO // Radiocarbon. Vol.44. P.167-80.

Sokolov I.M. 1971. [Postcranial skeleton of a Bison] // Proceedings of the Zoological Institute of USSR. Vol.48. P.198-219 [in Russian].

Stuiver M. \& Polach H.A. 1977. Discussion: reporting of ${ }^{14} \mathrm{C}$ data // Radiocarbon. Vol.19. P.355-363.

Stuiver M., Reimer P.J. \& Reimer R.W. 2013. CALIB 7.0. [on-line software and documentation, http:// radiocarbon.pa.qub.ac.uk/calib/calib.html].

[The unified regional stratigraphic scheme of the Quaternary deposits of the West Siberian Plain]. 2000. Siberian Research Institute of Geology, Geophysics and Mineral Resources, Novosibirsk. 64 p. [in Russian].

Tomirdiaro S.V. 1982. [Discussion problems of biostratigraphy of the Pleistocene deposits in the north-eastern USSR] // [The Mammoth Fauna of the Asian Part of the USSR]. Proceedings of the Zoological Institute of USSR. Vol.111. P.57-65 [in Russian].

van Klinken G.J. 1999. Bone collagen quality indicators for palaeodietary and radiocarbon measurements // Journal of Archaeological Science. Vol.26. No.6. P.687-695.

Vasiliev S.K. 2008. Late Pleistocene Bison (Bison p. priscus Bojanus, 1827) from the Southeastern part of Western Siberia // Archaeology, Ethnology \& Anthropology of Eurasia. Vol.34. No.2. P.34-56.

Ward G.K. \& Wilson S.R. 1978. Procedures for comparing and combining radiocarbon age determinations: A critique // Archaeometry. Vol.20. P.19-31. 